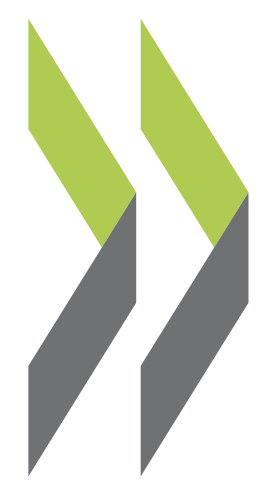

OECD Economics Department Working Papers No. 894

\title{
Greener Growth
}

in the Belgian Federation

\section{Tomasz Koźluk}




\section{Unclassified}

ECO/WKP(2011)63

Organisation de Coopération et de Développement Économiques

Organisation for Economic Co-operation and Development

29-Sep-2011

ECONOMICS DEPARTMENT

English - Or. English

GREENER GROWTH IN THE BELGIAN FEDERATION

ECONOMICS DEPARTMENT WORKING PAPER No. 894

By Tomasz Koźluk

All OECD Economics Department Working Papers are available on the OECD Intranet website at www.oecd.org/eco/workingpapers

JT03307813

Document complet disponible sur OLIS dans son format d'origine

Complete document available on OLIS in its original format 


\section{ABSTRACT/RESUME}

\section{Greener growth in the Belgian federation}

The degradation of the environment due to climate change and pollution can harm living standards and damage growth prospects. In Belgium, one of the most densely populated OECD countries, pressure on the environment is particularly strong, and is reinforced by the high energy intensity of the economy and concentrated agriculture. Environmental policy backlogs accumulated over the years highlight the challenges of reducing greenhouse gas emissions and water pollution in a cost-efficient way. To achieve environmental goals at minimum cost across the economy the polluters should face the marginal costs of the externalities they impose, which should be achieved by increasing reliance on environmental taxation. Potential adverse effects on income distribution could then be addressed in the tax benefit system. Moreover, where environmental responsibilities are better dealt with at the regional level, regions should have the most efficient tools, such as taxation powers. Where, due to economies of scale and scope or important cross-regional effects, environmental issues are better dealt with at the national level (for instance in renewable energy sources and transport policies), better co-ordination among regions or a greater role of the federal level should be envisaged. This Working Paper relates to the 2011 OECD Economic Review of Belgium (www.oecd.org/eco/surveys/Belgium).

JEL classification codes: Q28, Q48, Q53, Q54, Q58, R41, R48.

Keywords: Belgium; green growth; environmental policies; greenhouse gas emissions; energy efficiency; pollution; renewable energy; transport policies; road pricing; federalism

$* * * * * * *$

\section{Une croissance plus verte en Belgique}

La dégradation de l'environnement due au changement climatique et à la pollution peut porter atteinte au niveau de vie et aux perspectives de croissance. En Belgique, l'un des pays de l'OCDE les plus densément peuplés, la pression sur l'environnement est particulièrement forte, et encore aggravée par la haute intensité énergétique de l'économie et la concentration de l'agriculture. Les retards accumulés par la politique environnementale au fil des années accentuent encore le défi qui consiste à réduire, avec un bon rapport coût-efficacité, les émissions de gaz à effet de serre et la pollution de l'eau. Pour que les objectifs environnementaux soient atteints pour un coût minimal dans l'ensemble de l'économie, les pollueurs devraient supporter le coût marginal des externalités qu'ils imposent, ce qui devrait être obtenu par un recours accru à la taxation environnementale. Les conséquences indésirables qui pourraient en découler pour la répartition des revenus pourraient alors trouver une solution dans le cadre du système de prélèvements et de prestations. De plus, dans les cas où les responsabilités environnementales sont mieux prises en charge au niveau régional, les régions devraient disposer des outils les plus efficaces, tels que le pouvoir de taxation. Lorsque, en raison d'économies d'échelle et de gamme ou de la présence d'importants effets transrégionaux, les questions d'environnement relèvent davantage de l'échelon national (par exemple, les sources d'énergie renouvelables et les politiques de transport), une meilleure coordination des régions ou un rôle accru des autorités fédérales devraient être envisagés. Ce Document de travail se rapporte à l'Étude économique de l'OCDE de la Belgique 2011 (www.oecd.org/eco/etudes/Belgique).

Classification JEL : Q28, Q48, Q53, Q54, Q58, R41, R48,.

Mots clefs : Belgique; la croissance verte; les politiques environnementales; les émissions de gaz à effet de serre ; efficacité énergétique ; la pollution ; les énergies renouvelables ; les politiques de transport ; la tarification routière ; le fédéralisme

Copyright $\odot$ OECD, 2011. All rights reserved. Application for permission to reproduce or translate all, or part of, this material should be made to: Head of Publications Service, OECD, 2 rue André-Pascal, 75775 PARIS CEDEX 16, France. 


\section{TABLE OF CONTENTS}

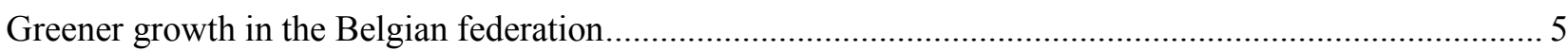

The greenhouse gas emission targets are becoming increasingly challenging........................................ 5

The high energy intensity of the economy leads to a large amount of emissions .................................... 9

Polluters must face the marginal cost of damages to ensure cost-efficient abatement............................ 24

Improvements in the area of water quality are visible, but suffer from a large backlog ........................ 28

Environmental tools and policies should be co-ordinated and realigned ................................................ 30

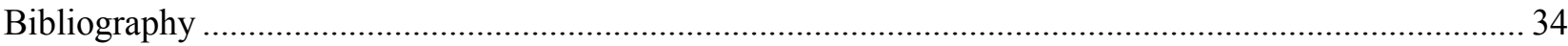

\section{Boxes}

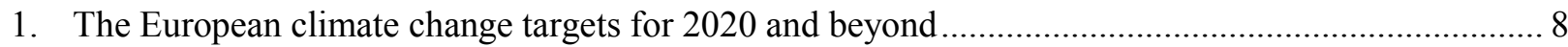

2. Federal climate change policies and the planned phase-out of nuclear energy .................................. 8

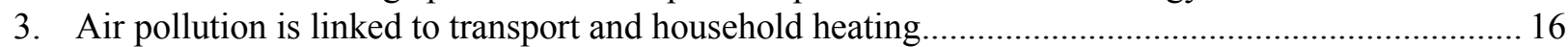

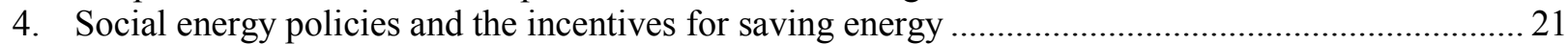

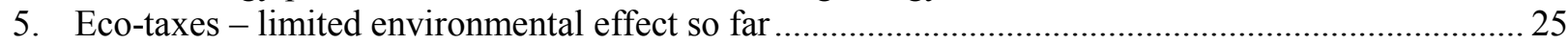

6. Cost-efficient "green" policies - polluters should face the marginal cost of externalities ................. 26

7. Environmental protection is costly, but should play a more important role.................................... 28

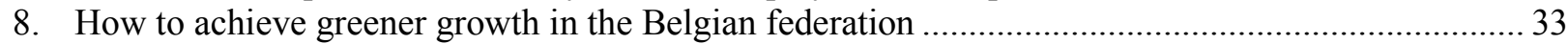

\section{Tables}

1. The burden-sharing of greenhouse gas emission reductions across Belgium .................................. 7

2. Various types of green certificates aim at encouraging renewable energy ................................... 13

3. There is a wide range of allowances to support commuting ...................................................... 18

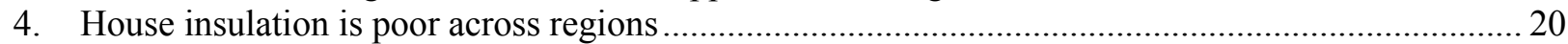

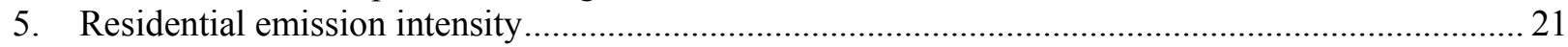

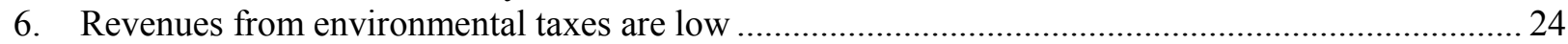

7. The implicit price of $\mathrm{CO}_{2}$ for different fuels and uses varies widely........................................... 25

8. Division of responsibilities in environmental and related policies is complicated ........................... 31

\section{Figures}

1. Greenhouse gas emissions have been reduced, partly because of the crisis .................................... 6

2. Energy intensity of the economy is high, while emission intensity is average ................................ 9

3. An internationally high share of GHG emissions comes from the industrial sector......................... 10

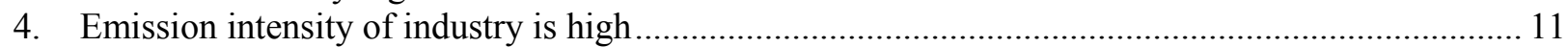

5. Effective taxes on energy are among the lowest in Europe ........................................................ 11

6. The share of emissions from transport and residential sectors has been increasing ......................... 14

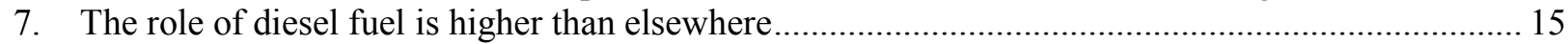

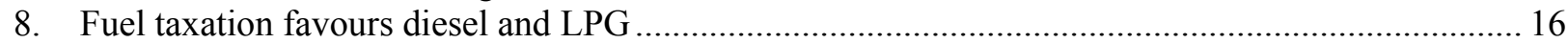

9. NOx emissions exceed targets to a larger extent than in other countries....................................... 16

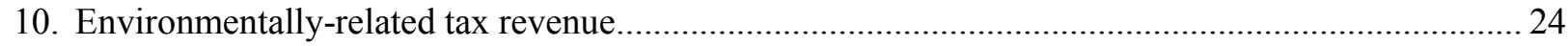

11. The share of population connected to wastewater treatment is low ............................................... 29

Disclaimer: This document and any map included herein are without prejudice to the status of or sovereignty over any territory, to the delimitation of international frontiers and boundaries and to the name of any territory, city or area. 
ECO/WKP(2011)63 
ECO/WKP(2011)63

\title{
Greener growth in the Belgian federation
}

\author{
By Tomasz Koźluk ${ }^{1}$
}

Over the past decade progress has been made in assuring sustainable development and a better and healthier life for Belgians (OECD, 2007a), but environmental performance is still often judged as disappointing. ${ }^{2}$ As further objectives are being set, the challenge for the coming years will be to meet them in a cost-efficient way. This paper goes through the areas of environmental policies where the problems are most pressing, starting from the goal of reducing greenhouse gas (GHG) emissions in this energy intensive economy. The slow development of renewable energy is also addressed in the context of climate change. Air quality, a particular problem in the main cities, is reviewed within this context of GHG emissions due to the interrelations between the two areas. Next, water pollution issues are discussed against the background of years of failing to meet European standards, and the intensive use of water resources. Finally, the division of environmental responsibilities is discussed, with the aim of assuring cost-efficient policies.

\section{The greenhouse gas emission targets are becoming increasingly challenging}

Belgium, as many OECD countries, is likely to fulfil its Kyoto commitments for 2008-12 (Figure 1). In the Kyoto protocol Belgium committed to a reduction of 2008-12 greenhouse gas (GHG) emissions by $7.5 \%$ with respect to 1990 , slightly less than the EU15 overall target of $-8 \%$. The federal government and the three regions signed an agreement specifying individual targets for each of them (Table 1). Together the regional targets yield a national reduction of emissions of $5.8 \%$ and the remainder is to be achieved by the federal government through the so-called Kyoto flexible mechanisms, such as the purchase of emission rights and emission-offsetting investments abroad. The regions may also use the flexible mechanisms to achieve their targets. ${ }^{3}$ The 2008-09 emissions have turned out significantly lower than initially expected, owing to the drop in activity due to the global crisis - in particular low capacity utilisation in industry and slower transport growth (Figure 1 and Table 1).

1. The Working Paper is based on Chapter 3 of the OECD's 2011 Survey of Belgium which was prepared under the responsibility of the Economic and Development Review Committee. The author is grateful for the valuable comments received on earlier drafts of this text from Jens Høj, Pierre Beynet, Alain de Serres, Andrew Dean, Robert Ford, Jean-Luc Schneider and Balazs Egert from the Economics Department. In addition, the author would like to thank Nils-Axel Braathen and Gerard Bonnis from the Environmental Directorate, Bert Brys from the Centre for Tax Policy and Administration, Kurt Van Dender and Stephen Perkins from the International Transport Forum and Maria Sicilia from the International Energy Agency for their valuable discussions and comments. Special thanks go to Agnès Cavaciuti for statistical assistance and to Maartje Michelson for editorial support.

2. For instance, the Environmental Performance Index, which ranks countries according to fulfilment of established environmental goals, puts Belgium in $88^{\text {th }}$ place among 163 countries - the lowest of all OECD and EU countries (EPI, 2010). According to WWF, Belgium's ecological footprint - a proxy for the unsustainability of resource use - is the fourth highest in the world (WWF, 2010).

3. Regional governments can finance the purchase of carbon emission permits (on the EU ETS market) by emitters, in excess of the allocated permits. In 2010, the Walloon government planned to finance permits for a total of EUR 40-60 million for Arcelor Mittal to restart a blast furnace. 
Looking forward, the climate change goals are becoming more ambitious. Within the EU's Climate and Energy Package (so called 20/20/20, Box 1) Belgium has committed to targets, for 2020 and beyond, by: participating in the EU's cap-and-trade Emission Trading Scheme (ETS), ${ }^{4}$ adopting Belgian targets on

Figure 1. Greenhouse gas emissions have been reduced, partly because of the crisis

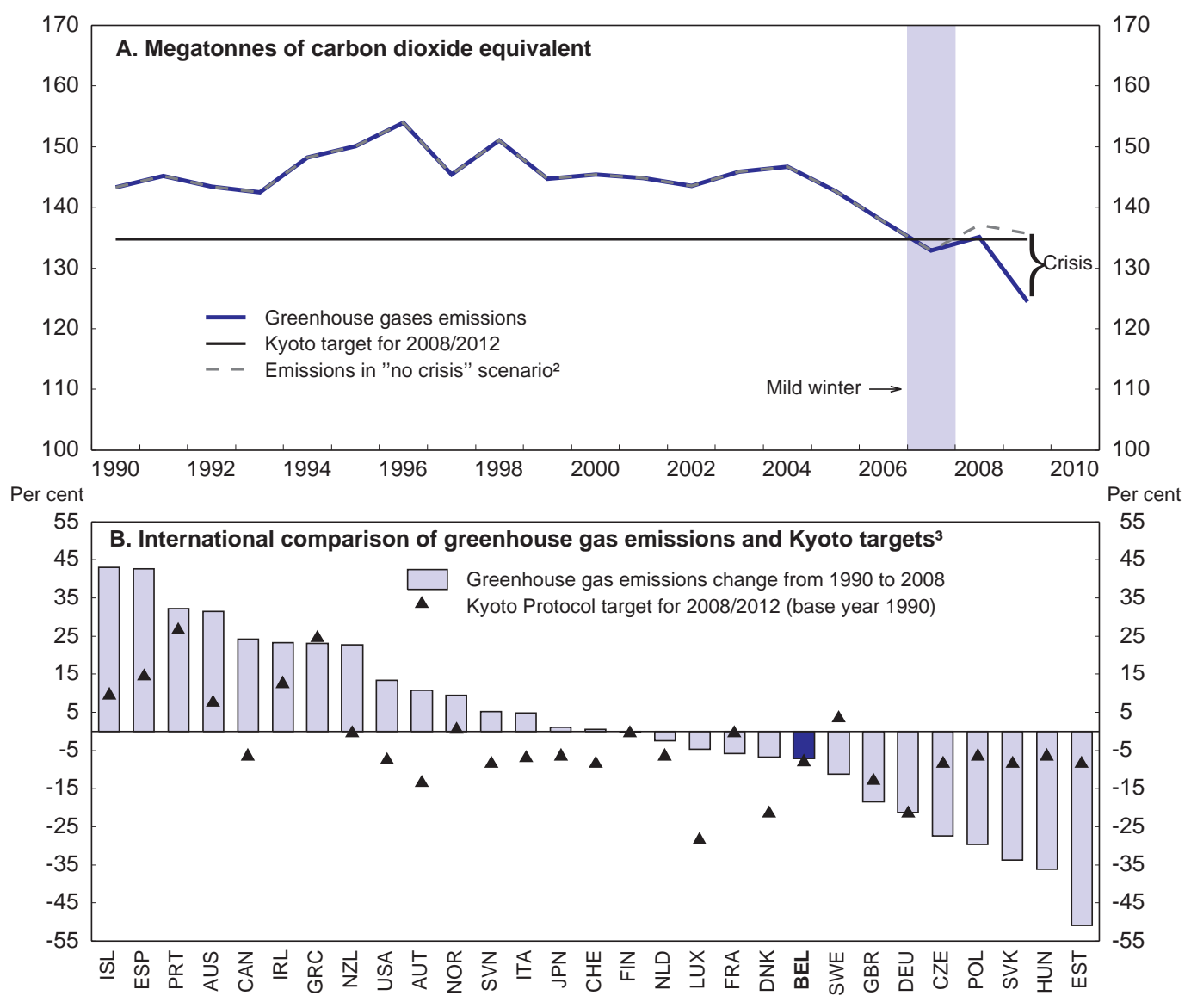

1. Total $\mathrm{CO}_{2}$ equivalent emissions without land use, land-use change and forestry.

2. The "no-crisis" scenario is obtained by assuming GDP growth in 2008 and 2009 is equal to the average growth over 1999-2007 and that the GHG-emission intensity of GDP in 2009 is equal to the value in 2008 adjusted by the average decrease in the intensity over 1999-2006 (proxying for the elimination of the mild winter effect of 2007).

3. The base year is 1986 for Slovenia, the average of the years 1985 to 1987 for Hungary and 1988 for Poland. The United States did not ratify the Kyoto protocol.

Source: Federal Public Service: Health, Food Chain Safety and Environment; United Nations Framework Convention on Climate Change Database.

4. The EU's Emission Trading Scheme is a GHG cap-and-trade scheme introduced in 2005 (Norway, Liechtenstein and Iceland also joined the scheme). It covers about 10000 installations in the energy and industrial sectors, which generate over $40 \%$ of GHG emissions in the countries concerned. Emission rights are allocated according to internationally agreed national caps and within the country according to national allocation plans (NAPs) $-96 \%$ through grandfathering. The Belgian NAP covers over $40 \%$ of projected emissions: roughly $80 \%$ of industrial emissions and $97 \%$ of emissions from the energy sector. The NAP reserves $8 \%$ of emission rights for new entrants. From 2012, the EU scheme will include air transport and increase the emphasis on auctioning (over $50 \%$ of permits throughout 2013-20) over grandfathering. 
reducing its non-ETS emissions by $15 \%$ (with respect to 2005) and increasing the share of renewable in energy consumption to 13\%. Additionally, Belgium has adopted a 2020 target of a reduction of primary energy consumption by $18 \%$ with respect to a 2007 baseline. These targets appear challenging since the baseline scenario (assuming no policy change) is an overall 13\% increase in GHG emissions by 2020 relative to 2005 (Bossier et al., 2008). The non-ETS segment is to see a 4\% increase. More recent estimates show that the crisis has slowed the increase in emissions (FPB, 2010), but even so the targets for 2020 and beyond are unlikely to be fulfilled without substantial new measures.

Table 1. The burden-sharing of greenhouse gas emission reductions across Belgium ${ }^{1}$

\begin{tabular}{|c|c|c|c|c|}
\hline \multirow[b]{2}{*}{ Units: $\mathrm{MtCO}_{2} \mathrm{eq}$} & \multirow[b]{2}{*}{$\begin{array}{l}\text { Base year GHG } \\
\text { emissions }\end{array}$} & \multirow{2}{*}{$\begin{array}{c}\text { Commitment (2008-12) } \\
\begin{array}{c}\text { Average reduction w.r.t. } \\
\text { base year }\end{array}\end{array}$} & \multicolumn{2}{|c|}{ Actual result ${ }^{2}$} \\
\hline & & & $\begin{array}{l}2008 \text { change } \\
\text { from base year }\end{array}$ & $\begin{array}{l}2009 \text { change } \\
\text { from base year }\end{array}$ \\
\hline Wallonia & 54.7 & $-7.5 \%$ & $-12.2 \%$ & $-26.7 \%$ \\
\hline Flanders & 87.0 & $-5.2 \%$ & $-4.7 \%$ & $-7.8 \%$ \\
\hline Brussels-Capital $^{3}$ & 4.0 & $+3.4 \%$ & $+3.9 \%$ & $+1.1 \%$ \\
\hline Total & 145.7 & $-5.8 \%$ & $-7.3 \%$ & $-14.6 \%$ \\
\hline Kyoto commitment & 134.8 & $-7.5 \%$ & $-7.5 \%$ & $-7.5 \%$ \\
\hline \multicolumn{2}{|c|}{$\begin{array}{l}\text { Federal government commitment through Kyoto } \\
\text { mechanisms }\end{array}$} & $1.7 \%$ & - & - \\
\hline
\end{tabular}

-: not available.

1. Results excluding LULUCF, base year is 1990 for all GHG gasses, 1995 for fluorinated gasses.

2. The emission outcomes are presented for illustrative purposes, and are not directly comparable with the emission targets, due to the fact that the targets include the ETS segment. The emission permits for the ETS segment are allocated in line with country targets can be saved for future years, as well as traded on the ETS.

3. Provisional figures 2008 and 2009.

Source: International Energy Agency (IEA), Energy Policies of IEA Countries: In-depth review of Belgium, 2009; Regional and Federal governments.

For the moment, in Belgium there is no clear national strategy on how the 20/20/20 goals are to be achieved (Box 2), but it is likely that the governments will sign an internal agreement, as in the case of Kyoto targets. If such an agreement will mean different $a d$ hoc targets in each region, implying different carbon prices, it will make abatement at minimum cost difficult, due to limited price equalisation mechanisms for the non-ETS segment. Nationwide reduction strategies would be hence preferable. 
$\mathrm{ECO} / \mathrm{WKP}(2011) 63$

\section{Box 1. The European climate change targets for 2020 and beyond}

For 2020 and beyond, all EU countries committed under the climate and energy package (so called 20/20/20) to:

- $\quad$ Reducing EU-wide GHG emissions by $20 \%$ relative to 1990 . This includes a $21 \%$ cut (relative to 2005 ) in industries under the ETS and a 10\% cut in non-ETS sectors (transport, residential, services and agriculture). Each country has an individual target - Belgium committed to the new cuts under the ETS and to cutting emissions by $15 \%$ in the non-ETS sectors.

- Doubling the overall EU share of renewable energy in final energy consumption to $20 \%$ (10\% specifically in the transport sector). The Belgian commitment is to increase its share of renewables to $13 \%$.

- Improving energy efficiency by $20 \%$, on the EU level.

The EU climate change and energy package also contains a commitment to further reduce emissions (in total by $30 \%$ ) if an international agreement with other major emitters is reached.

There are a number of direct consequences of the package for Belgium (as well as for other EU countries). Firstly, the effective separation between the ETS and non-ETS targets combined with a lack of market mechanisms between the two segments means that it is likely that abatement costs are going to differ between the ETS and the non-ETS segments. Hence, pure minimum-cost abatement will not be possible, meaning that there is likely to be too much abatement in one segment, while cheaper abatement possibilities in the other will not be exploited. Second, the individual targets are characterised by strong interactions. For instance, increasing the (Belgian) share of renewable energy in terms of electricity production, while likely to reduce the $\mathrm{CO}_{2}$-intensity of the Belgian economy, may not lead to any reduction in EU-wide $\mathrm{CO}_{2}$ emissions, as long as the ETS cap remains fixed. In a similar manner, improvements in, for example, household energy efficiency that reduce (Belgian) electricity use, will only decrease the price of emission permits on the ETS, but not reduce EU-wide emissions (OECD, 2011b).

\section{Box 2. Federal climate change policies and the planned phase-out of nuclear energy}

Over half of Belgian electricity production takes place in nuclear power plants which constitute the majority of base load capacity. On current plans (a 2003 law) nuclear energy is to be phased out between 2015 and 2025 . In 2009 the government took a decision to postpone the phase-out of the three oldest nuclear reactors by 10 years, but the bill has not yet been voted. The full depreciation of the nuclear reactors creates a windfall profit for nuclear producers, which the government is attempting to tax away. The level of the tax is under discussion,

Federal strategies regarding climate change and energy policies focus on increasing the role of renewable energy sources - from below $4 \%$ of total energy consumption currently to $13 \%$ by 2020 . As smaller scale renewable energy sources are a regional competence, the main plans are for off-shore wind energy (2000 MW of windmill parks in the North Sea), biomass (adapting two major coal plants) and bio fuels (encouraging the share in fuel transport via a quota system). These measures are to reduce emissions by $4 \%$. For the moment, implementation of the plans is lagging - for example windmill developments are delayed because of regulatory issues (capacity constraints on the connection to the grid and bureaucratic procedures). The government also plans to increase interconnection capacity with neighbouring countries (in 2008 net imports of electricity were over $10 \%$ of total electricity use). Other measures will yield minor effects.

The replacement of nuclear energy is likely to result in increasing overall $\mathrm{CO}_{2}$ emissions by $12-20 \%$, depending on the assumptions. The phase-out may not be directly relevant for the $20 / 20 / 20$ targets, since there is no "Belgian" target for the ETS segment - replacing nuclear with fossil fuel plants will increase the ETS price of emission permits, inducing more abatement somewhere across the EU. The resulting increase in electricity prices may have some secondary effects on the composition of energy demand, as the relative price of high-emission fossil fuels will decrease. Still, there are currently no clear plans on how to replace nuclear. According to a sustainable development scenario (GEMIX simulations), a full phase out of nuclear energy would imply an energy mix with about $40 \%$ of energy coming from windmill farms by 2050 . Such an outcome is likely to be expensive due to the limited physical space for off-shore windmill plants, and problematic in practice due to their poor reliability to provide base or peak load. 


\section{The high energy intensity of the economy leads to a large amount of emissions}

Despite a slight decrease over the past decade, Belgium's energy intensity of GDP remains above the OECD average (Figure 2). The reliance on no-emission nuclear energy reduces overall GHG emissionintensity, but is offset by the widespread use of oil products and one of the lowest shares of renewable energy in the OECD. Overall, emission intensity is above the EU average. Energy-intensive industry generates almost a third of overall GHG emissions, a higher share than in the majority of OECD countries (Figure 3). Road transport contributes a fifth of emissions (roughly the EU average) while residential emissions have the second highest share in the OECD.

Figure 2. Energy intensity of the economy is high, while emission intensity is average

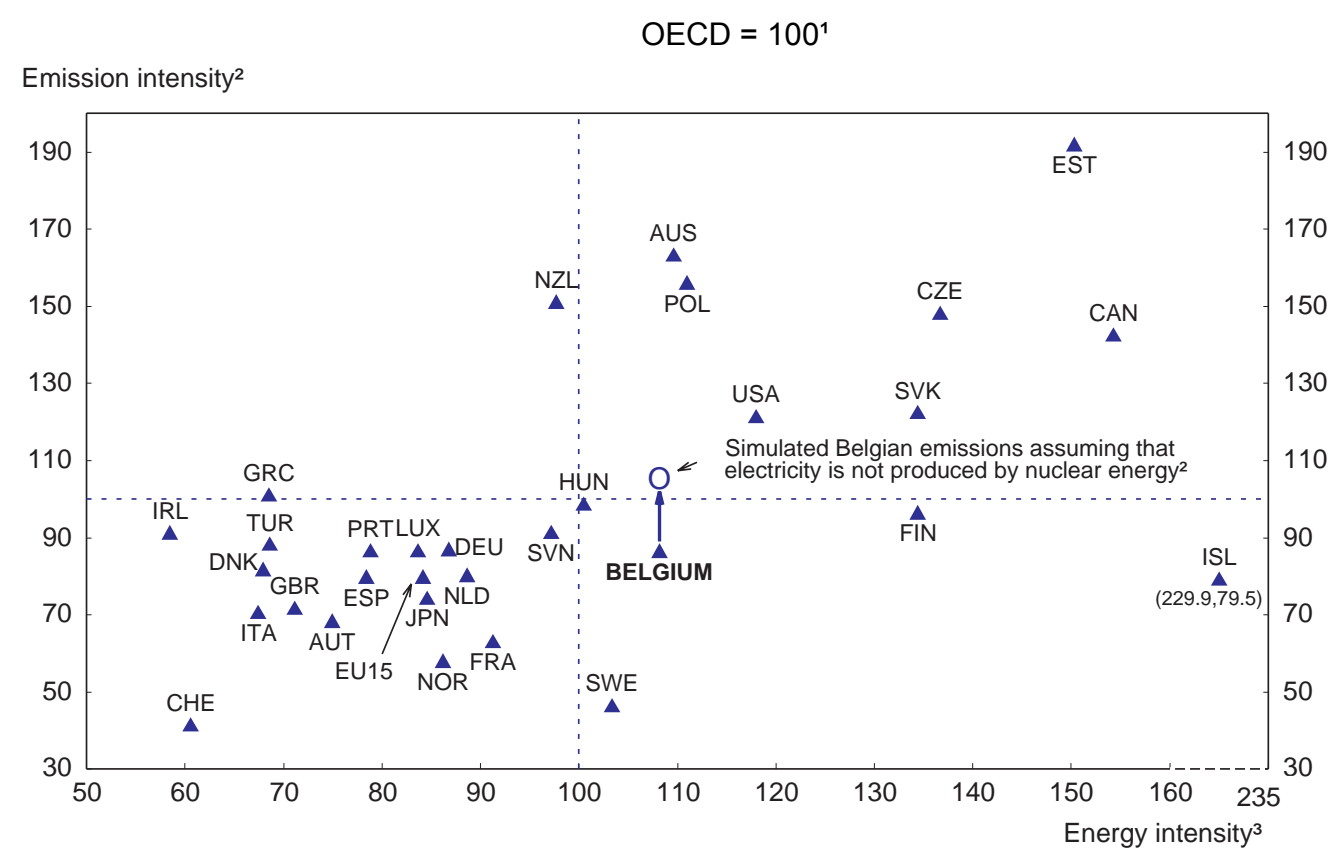

1. The OECD and EU15 aggregates are unweighted averages for 2003-08. For emission intensity, the OECD aggregate does not include Chile, Israel, Korea and Mexico.

2. Emission intensity is defined as GHGs excluding land-use, land-use change and forestry, in thousand tons of $\mathrm{CO}_{2}$ equivalent divided by GDP in 2000 USD using PPPs. Simulated Belgian emissions are shown for illustrative purposes only, given the envisaged phase-out of nuclear energy. They are computed as: (total GHGs emissions + GHGs from energy industries )/GDP in 2000 USD using PPPs. Implicitly this assumes no-emissions nuclear (roughly half of the electricity production)is replaced by current (non-nuclear) electricity production mix.

3. Energy intensity is measured by total primary energy supply (TPES) expressed in tons of $\mathrm{CO}_{2}$ equivalent divided by GDP in 2000 USD using PPPs.

Source: OECD, World Energy Balances Database and United Framework Convention on Climate Change Database. 
Figure 3. An internationally high share of GHG emissions comes from the industrial sector As a percentage of total GHG emissions, ${ }^{1} 2008$

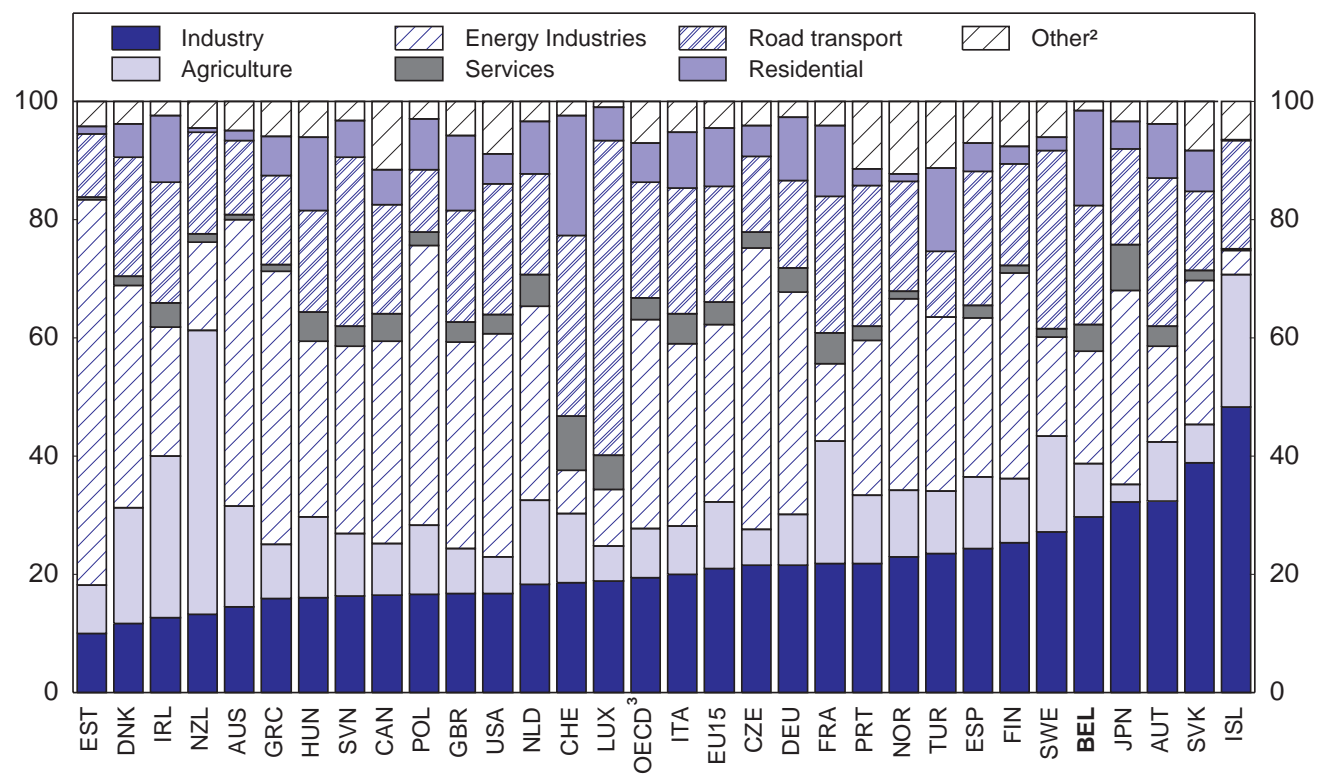

1. Total $\mathrm{CO}_{2}$ equivalent emissions without land use, land-use change and forestry.

2. Includes waste, other transport, solvent and other product use and other not elsewhere specified.

3. The OECD aggregate is an unweighted average and excludes Chile, Korea and Mexico.

Source: United Nations Framework Convention on Climate Change Database.

\section{Cheap energy has encouraged an energy-heavy production mix}

The energy intensity of Belgian industry is some $50 \%$ higher than in the EU15 (IEA, 2010), explaining the high GHG emission intensity (Figure 4, Panel B). The industry structure cannot entirely explain the high energy intensity, as the value added share of energy intensive industries (9\%) is basically equal to the EU average (McKinsey, 2009). The low employment rate (OECD, 2011a) suggests the production mix may be a result of years of a combination of relatively high labour costs together with relatively low energy prices, potentially leading to a substitution away from labour to energy (arguments in favour of such substitution can be found in Bassilière et al., 2005). The relative prices reflect the high level of taxes on labour and low energy taxation (Figure 5), with excise rates for most fuels being at or close to EU minima, some even at zero rates. ${ }^{5}$ Belgium also makes use of most of the exemptions to excise taxation available under EU law (HCF, 2009 and IEW, 2007) - for example, large users with an accord or permis environnemental face excise tax reductions on fuels up to $100 \%$ (HCF, 2009).

5. According to the Confederation Fiscal Europeen of the 14 main fuels listed by the EU, in Belgium 7 are subject to excise levies at minimum EU requirements and four have slightly higher values. For comparison, in France four fuels are taxed at minimum EU levels, while in Germany and the Netherlands none. 
Figure 4. Emission intensity of industry is high ${ }^{1}$
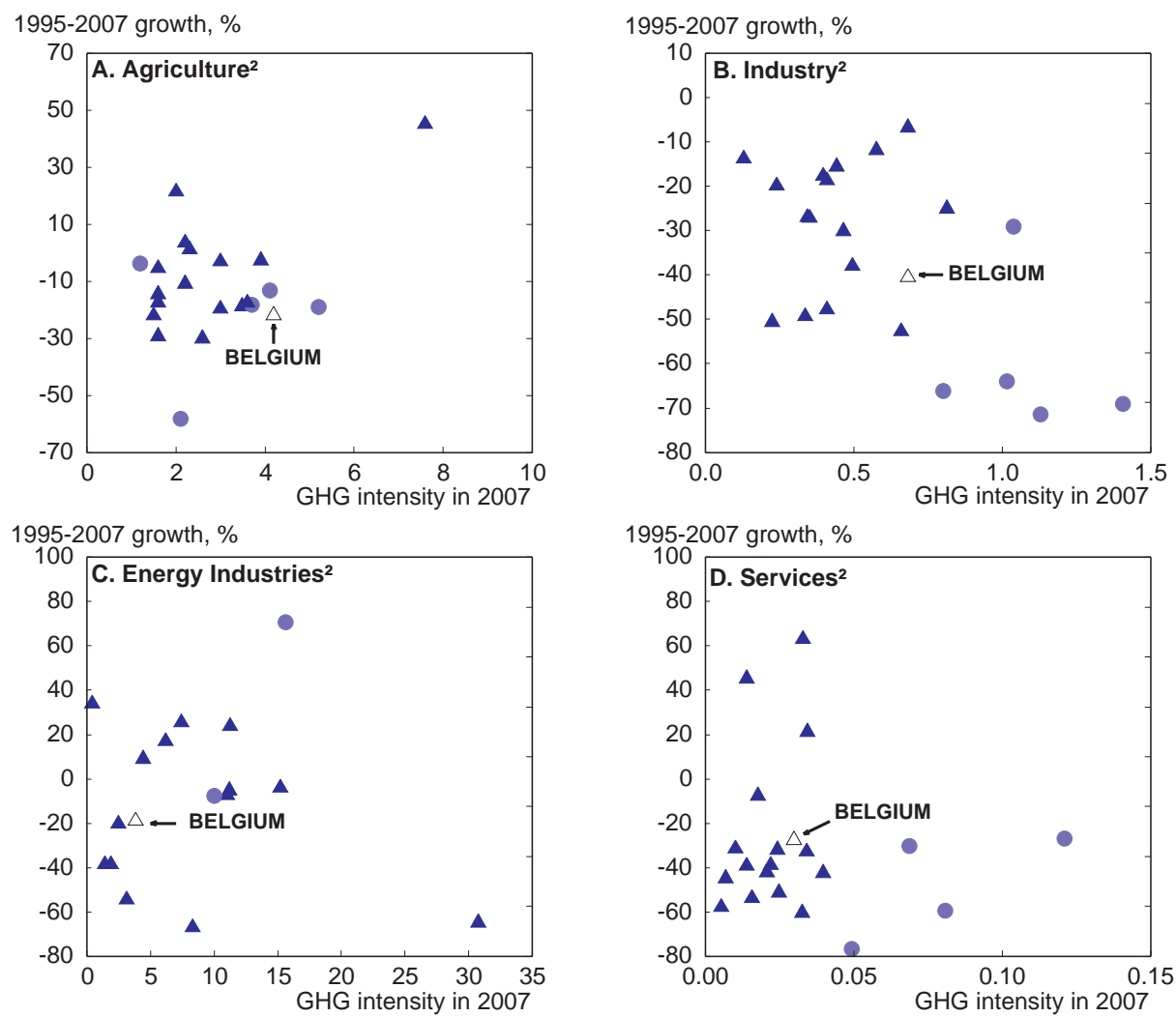

1. Greenhouse gas emission intensity is defined as kilogrammes of greenhouse gases (in $\mathrm{CO}_{2}$ equivalent) per thousand of sector gross value added (in euros and in constant prices of 2000). Change since 1999 for France, since 2000 for Greece and since 1997 in agriculture and services for Switzerland. The last available year is 2006 for Luxembourg, 2007 for Austria, Portugal and Turkey and 2005 for Denmark and The UK.

2. The circles represent Czech Republic (absent in Panel C), Hungary, Poland (absent in Panel C), Slovak Republic and Turkey (absent in Panels $\mathrm{C}$ and D).

Source: United Nations Framework Convention on Climate Change Database and Eurostat.

Figure 5. Effective taxes on energy are among the lowest in Europe

EUR per tonnes of oil equivalent (TOE), base year 2000

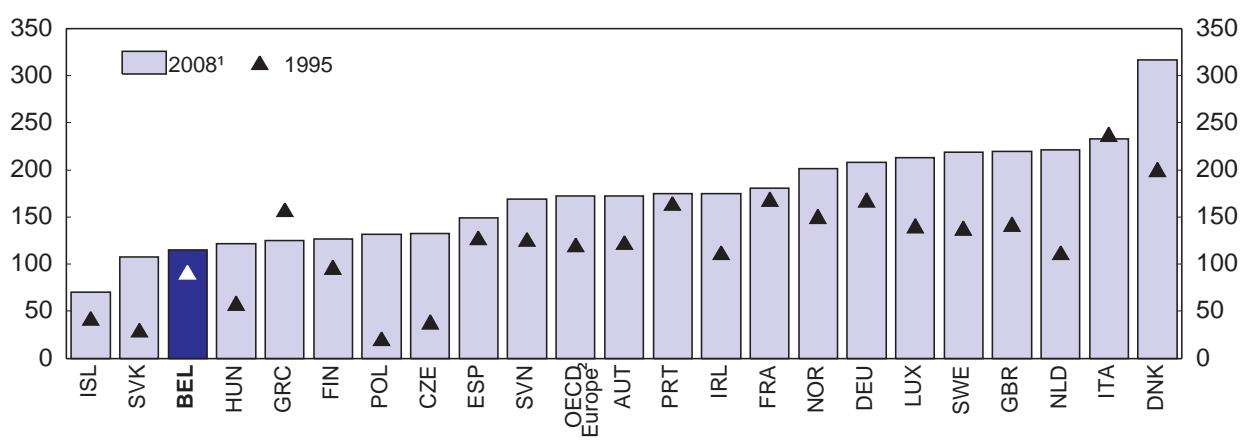

1. The last available year is 2007 for France and Greece and 2006 for Iceland.

2. The OECD Europe aggregate is a simple average and does not include Switzerland and Turkey.

Source: European Commission (2010), "Taxation trends in the European Union: Data for the EU Member States, Iceland and Norway". 


\section{The development of renewable energy sources is expensive}

A particular challenge that faces the Belgian economy, in terms of climate change targets, is the development of renewable energy. At the current state of technology, Belgium has limited natural advantages in terms of renewable energy: the marine territory is limited reducing the potential for off-shore windmills, while the largely flat landscape and moderate climate limit the potential for hydropower and solar energy. Furthermore, legal and regulatory problems, such as the fact that grid operators in Flanders regularly refuse to connect renewable energy producers and disputes on who should bear the connection costs, appear to raise entry costs to higher levels than in other countries (AEON, 2010). The result is one of the lowest shares of renewables in electricity production in the OECD, coming mainly from biomass, mostly imported from overseas. Pre-crisis simulations showed that the share of energy from renewable sources was to reach about $7.5 \%$ by 2020 - just above half of the Belgian target (Bossier et al., 2008). The effect of the crisis (lower overall energy consumption) and measures taken since 2008 should have a positive effect on the share of renewables, nevertheless, without further measures, it seems highly unlikely Belgium will meet its renewable targets.

To encourage the production of electricity from renewable sources, the federal and regional governments have introduced green certificates (GC's, Table 2). In line with the division of environmental (and energy) responsibilities, the federal level is responsible for certificates concerning energy producers connected to the high voltage grid, while the regional certificates concern the low voltage grid. ${ }^{6}$ Green certificates are issued to renewable energy producers by the relevant energy regulators. Each electricity grid operator is obliged to purchase all electricity from renewable producers at a market wholesale price. As the costs of renewable energy are generally higher than the wholesale market price, the green producers are compensated with gains from selling the GC's (either on the secondary GC market or to the grid operator directly for a minimum price). The grid operator also places the acquired certificates on the secondary market and can recuperate the difference between the cost of purchase of the GC's on the primary market and the secondary market price through distribution tariffs. On the secondary market, the GC's are purchased by the final electricity suppliers, each of which is obliged to acquire a certain minimum share of its electricity from renewable sources (in 2010 these were $2.8 \%$ in BCR, $6 \%$ in Flanders and $10 \%$ in Wallonia). This is done symbolically by acquiring a sufficient amount of GC's.

The renewable policies are poorly co-ordinated across governments, resulting in five separate GC markets and making renewable policy unnecessarily expensive. The national programme (National Action Plan) for renewable energy is effectively a compilation of federal and regional programmes with little mention of intranational spillovers and coordination of the strategies on how to achieve the 2020 target. In practice, regions set their own objectives and use different tools to achieve them, choosing individually the winning technologies and disregarding the marginal abatement costs. In the absence of a price equalisation mechanism, market separation fails to exploit economies of scale and scope - regional GC's do not guarantee that investments in renewables are done where it is economically most viable (across the country), raising the costs of achieving the overall objective. The existence of five (relatively small) separate GC markets also raises administrative costs, and remains an international peculiarity; for instance Norway and Sweden are taking steps to create a common market. ${ }^{7}$

\footnotetext{
6. The federal government certificates cover the grid above $70 \mathrm{kV}$.

7. The fifth separate market exists for combined heat and power production in Flanders. The separation is complete aside the agreement to accept Walloon GC's in Brussels on certain conditions.
} 
ECO/WKP(2011)63

Table 2. Various types of green certificates aim at encouraging renewable energy

Prices in EUR per MWh, 2010

\begin{tabular}{|c|c|c|c|c|}
\hline & Federal state & Walloon region & Flemish region & BCR \\
\hline \multicolumn{5}{|l|}{ Minimum prices } \\
\hline Offshore wind (first 216 MW) & 107 & & & \\
\hline Offshore wind (> $216 \mathrm{MW})$ & 90 & & & \\
\hline Onshore wind & 50 & 65 & 90 & - \\
\hline Photovoltaic & 150 & $455^{1}$ & $350^{2}$ & - \\
\hline Hydro & 50 & 65 & 90 & - \\
\hline Biomass & 20 & $6.5-130$ & 90 & - \\
\hline Geothermal & 20 & 65 & 90 & - \\
\hline Others & 20 & $6.5-26$ & 60 & - \\
\hline \multirow{2}{*}{$\begin{array}{l}\text { GC secondary market price (2009) } \\
\text { GC tradability }\end{array}$} & - & 88 & 107 & 86 \\
\hline & $\begin{array}{l}\text { No market, not } \\
\text { recognised by regions }\end{array}$ & Walloon only & Flanders only & $\begin{array}{l}\text { BCR and } \\
\text { Wallonia }\end{array}$ \\
\hline Combined Heat and Power & No & Yes & Separate system & Yes \\
\hline Compulsory acquisition & Transmission operator & $\begin{array}{l}\text { Local grid } \\
\text { operator }\end{array}$ & $\begin{array}{l}\text { Distribution } \\
\text { operator }\end{array}$ & $\begin{array}{c}\text { Local grid } \\
\text { operator }\end{array}$ \\
\hline
\end{tabular}

1. The minimum price for a GC in Wallonia is EUR 65. The system is based on $\mathrm{CO}_{2}$ avoidance (not MWh of energy produced) so a $5 \mathrm{~kW}$ PV plant will receive 7 green certificates per MWh, each subject to the minimum price. The number of certificates will decrease with the plant size. For hydro, wind and others the number of GC/MWh is 1 . The system is currently under revision.

2. Reduced annually by EUR 20/MWh until 2013 and by EUR 40/MWh onwards. The contracted price is guaranteed for 20 years.

Source: CREG and BRUGEL.

The fact that federal certificates are not accepted on the regional markets effectively excludes large scale production of renewable energy from the regional quotas and thus favours smaller, and likely lessefficient, producers at the regional level. Indeed, when compared with the $55 \mathrm{EUR}$ per MWh estimated increase in energy prices necessary to achieve the 2020 renewable targets (by making renewable energy economically viable), the regional GC's appear significantly overpriced, while the majority of the federal GC's are too cheap (Bossier et al., 2008). ${ }^{8}$ The former provide massive returns on low-risk investments in technologies with poor efficiency, ${ }^{9}$ and have practically no effect on EU-wide $\mathrm{CO}_{2}$ emissions (Box 1). The excessive prices may have negative environmental consequences, as by raising the final consumers' electricity bill they increase the incentives to switch to more polluting fossil fuels. Therefore, a common GC could be an efficient solution (De Serres et al., 2010).

Mandatory minimum prices for certain renewable energy technologies mean that governments are heavily involved in picking winning technologies (particularly photovoltaic) and risk limiting the incentives to improve their efficiency. To avoid a bias to expensive sources, the single GC market should not be bound by minimum prices. Instead, the price of renewable energy, and consequently the development of the cheapest and most appropriate technologies, should be left to the market under the constraint of a credible national path for the mandatory minimum share of renewable energy. The reductions in GC's requirements for suppliers of large clients (currently in place in all regions) are effectively a subsidy to these clients, that is, to large energy consumers, and should be abolished.

8. Recalculated to 2010 prices, the scenario also requires a carbon price.

9. CREG (2010b) takes into account all implicit and explicit (federal and regional) government aid in Flanders - tax deductions, investment subsidies, and GC's to calculate the annual returns on equity of $55 \%$ for PV, over 100\% for onshore wind and biomass and in excess of $1000 \%$ for biomass co-combustion in existing coal plants. A similar study for Wallonia was not possible due to the lack of data. 
Renewable energy is also encouraged through a number of investment subsidies and tax reductions. At the federal level, households can deduct up to $40 \%$ of their investment in renewable energy from income tax. Enterprises can deduct $13.5 \%$ of their investment in renewable energy from the taxable profits. The federal government also provides implicit subsidies to off-shore wind - through minimum prices on the GC market, connector cables, covering part of balancing costs and government-backed loans from the European Investment Bank (CREG, 2010a). The Flemish government provides investment subsidies to enterprises $-10-20 \%$ (to double in the future) of the additional costs of investments in renewables ${ }^{10}$ (Guisson and Marchal, 2008). Wallonia provides specific grants for small biomass and combined heat and power plants (IEA, 2010). A common, well-designed GC scheme and low market entry barriers would ensure the viability of investments in the most efficient renewable technologies across the country and improve incentives for $R \& D$ in this area.

\section{Transport is imposing an increasing burden on the environment}

The transport sector, as in most EU countries, has undergone the largest growth in emissions since 1990 (Figure 6), reflecting increases in traffic volumes (among the highest in the EU15) only partly offset by better emission performance of vehicles. Particularly high growth of freight transport volumes mirrors increases in world trade as half of the freight traffic is international (Hertveldt et al., 2009). Passenger transport reflects intensive commuting, mostly by car with the use per capita among the highest in the OECD. Inland freight transport is mainly on roads, with an internationally high share of inland waterways. The road, motorway and rail networks are well developed and among the most dense in the OECD, but congestion is a frequent feature in bottleneck areas, in particular in the area of Brussels (among the most congested cities in Europe; Le Soir, 2010) and Antwerp. On current policies, emissions from transport are expected to continue growing over the next decade (Bossier et al., 2008).

Figure 6. The share of emissions from transport and residential sectors has been increasing As a percentage of total GHG emissions, ${ }^{1} 2008$

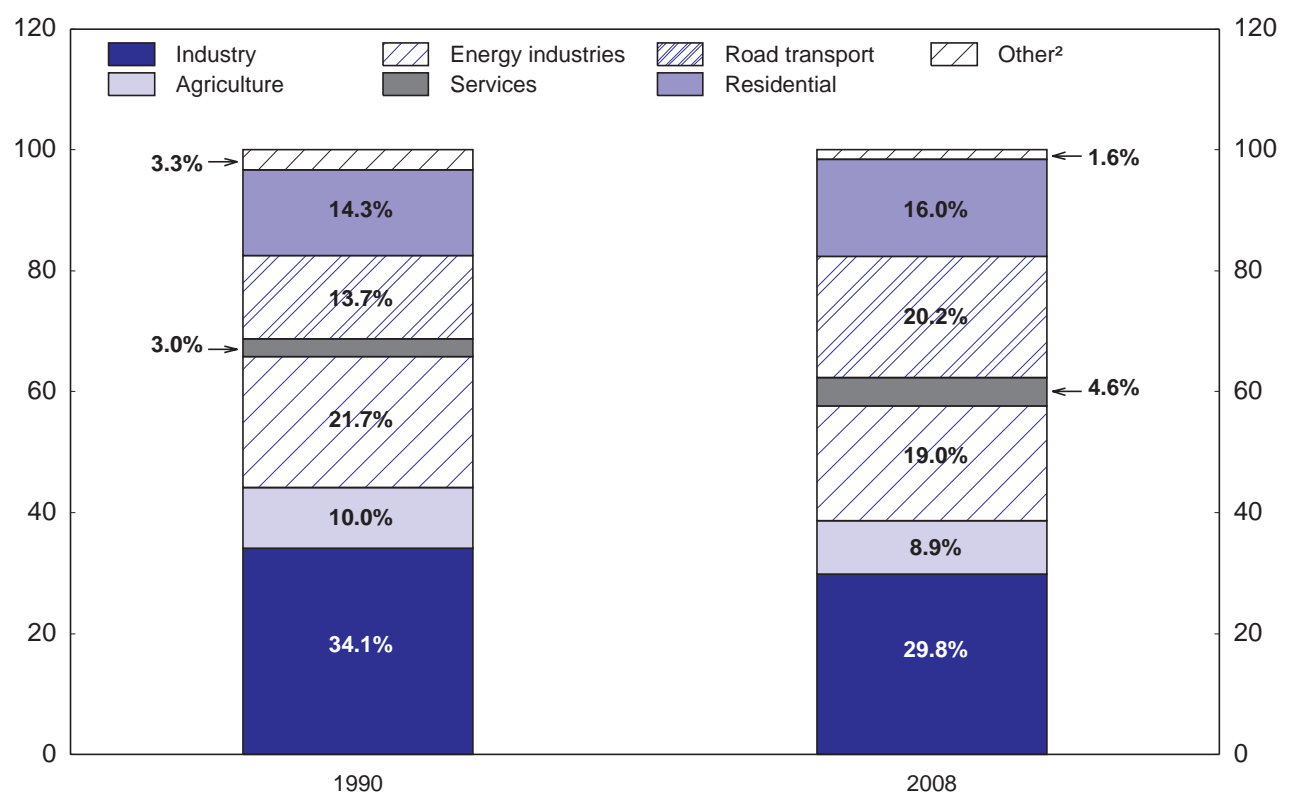

1. Total $\mathrm{CO}_{2}$ equivalent emissions without land use, land-use change and forestry.

2. Includes waste, other transport, solvent and other product use and other not elsewhere specified.

10. Additional costs with respect to standard technology are defined as $50 \%$ of the costs of investment in biomass electricity and co-generation and $80 \%$ of biomass heat generation. SME's receive $20 \%$, large companies $10 \%$ with a limit of EUR 1.5 million. 
Source: United Nations Framework Convention on Climate Change Database.

A particular feature is the internationally high share of diesel use (Figure 7), reflecting the dieseldominance of Belgian passenger cars $(57 \%$, second only to Luxembourg in the OECD, driving some $70 \%$ of the vehicle-kilometres) and an important role of international transport. This results, to a large extent, from the relatively low taxation of diesel fuels (Figure 8), which is some $40 \%$ lower (excise taxation, per litre) than gasoline, despite its $15 \%$ higher carbon content and higher related emissions of other pollutants such as $\mathrm{NO}_{\mathrm{x}}$ and particulate matter. The two latter are a major problem, in particular in Brussels (Box 3). Furthermore, low diesel prices lead to a "diesel illusion" - one in four Belgians that opt for diesel do not drive enough to make this choice financially viable and would be better off buying a gasoline car (VAB, 2008).

Figure 7. The role of diesel fuel is higher than elsewhere ${ }^{1}$

Ratio of purchased diesel to gasoline, ${ }^{2} 2008$

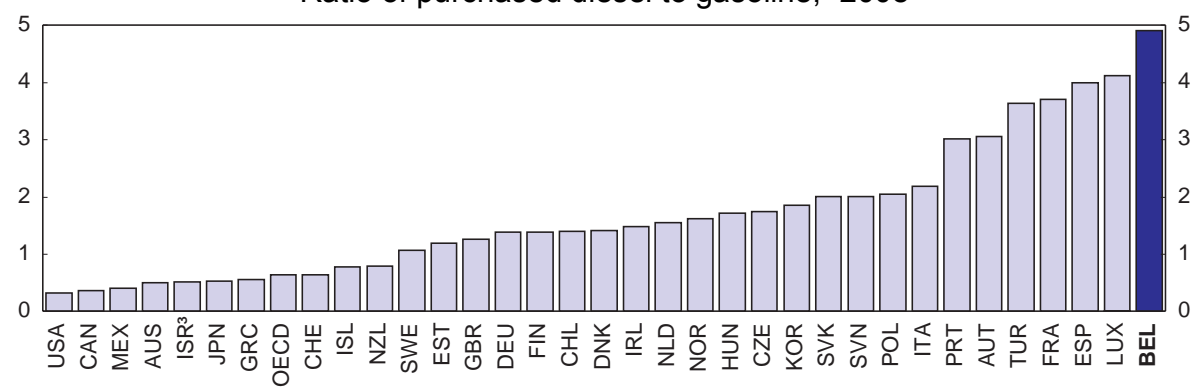

1. Diesel refers to biodiesels and gas/diesel oil in kilotonnes and gasoline refers to biogasoline and motor gasoline in kilotonnes.

2. Ratio of diesel consumption to gasoline consumption.

3. The statistical data for Israel are supplied by and under the responsibility of the relevant Israeli authorities. The use of such data by the OECD is without prejudice to the status of the Golan Heights, East Jerusalem and Israeli settlements in the West Bank under the terms of international law.

Source: OECD, OECD World Energy Statistics Database.

\section{Box 3. Air pollution is linked to transport and household heating}

The two main problems with air quality in Belgium are nitrogen di-oxide $\left(\mathrm{NO}_{2}\right)$ emissions and particulate matter (particularly $\mathrm{PM}_{10}$ ), both largely due to the widespread use of diesel fuels in transport and heating. In the case of particulate matter, the agricultural sector is also an important emission source. As most EU countries, Belgium is likely to have met the 2010 EU targets for all pollutants apart from nitrogen oxides $\left(\mathrm{NO}_{\mathrm{x}}\right)$ but the margin by which the $\mathrm{NO}_{x}$ target has been missed is among the highest (Figure 9). For particulate matter, excess concentration is among the most widespread among the EU15 with almost all the monitored zones exceeding the daily (though not the annual) limits. The problems are particularly acute in Brussels and Antwerp. Overall, the problems with complying with the EU's daily limit values for $\mathrm{PM}_{10}$ are likely to persist for many years to come (Fierens et al., 2006, Deutsch et al., 2010). 


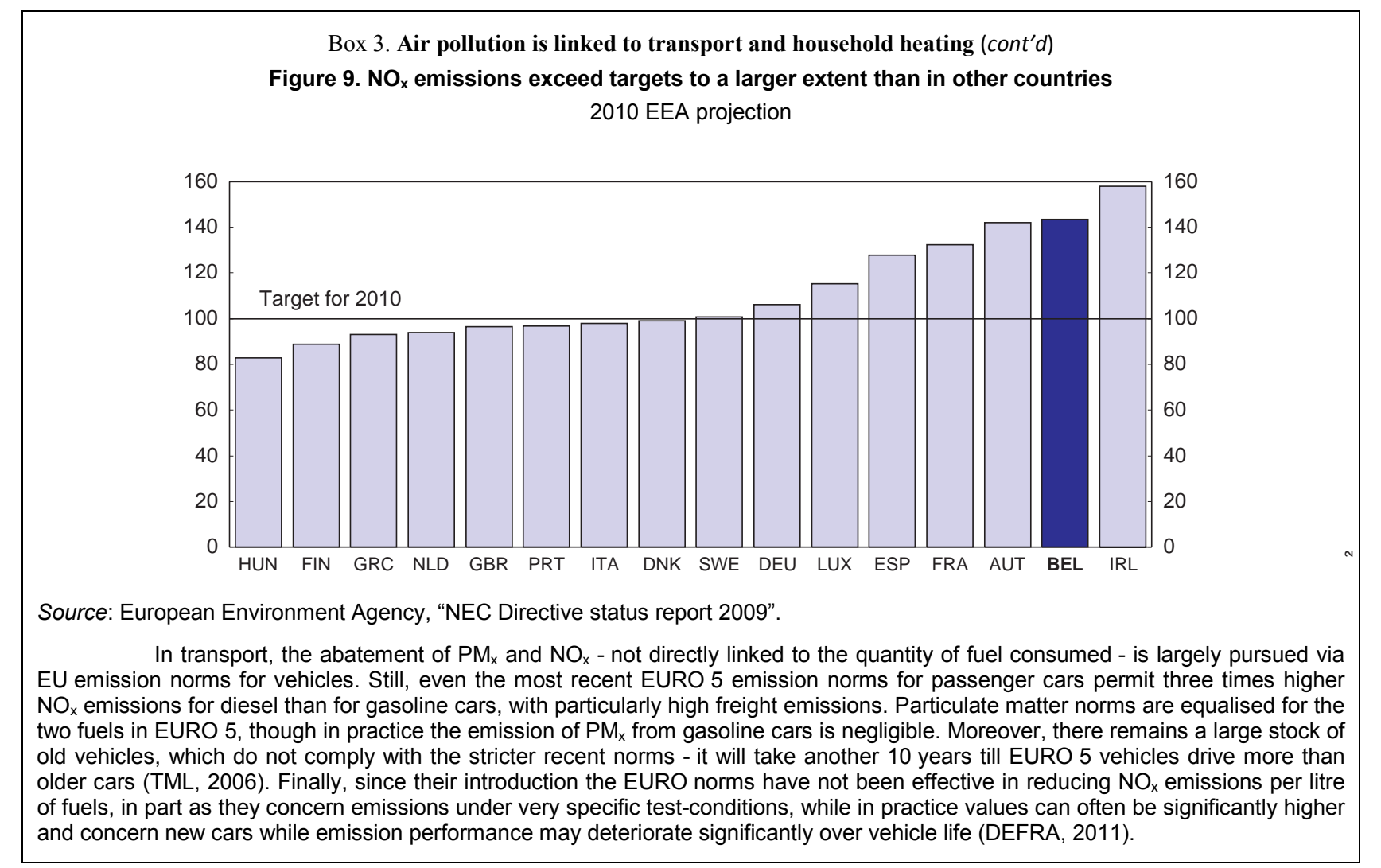

Figure 8. Fuel taxation favours diesel and LPG

Percentage of taxes (excluding value added tax) in fuel prices, 2010

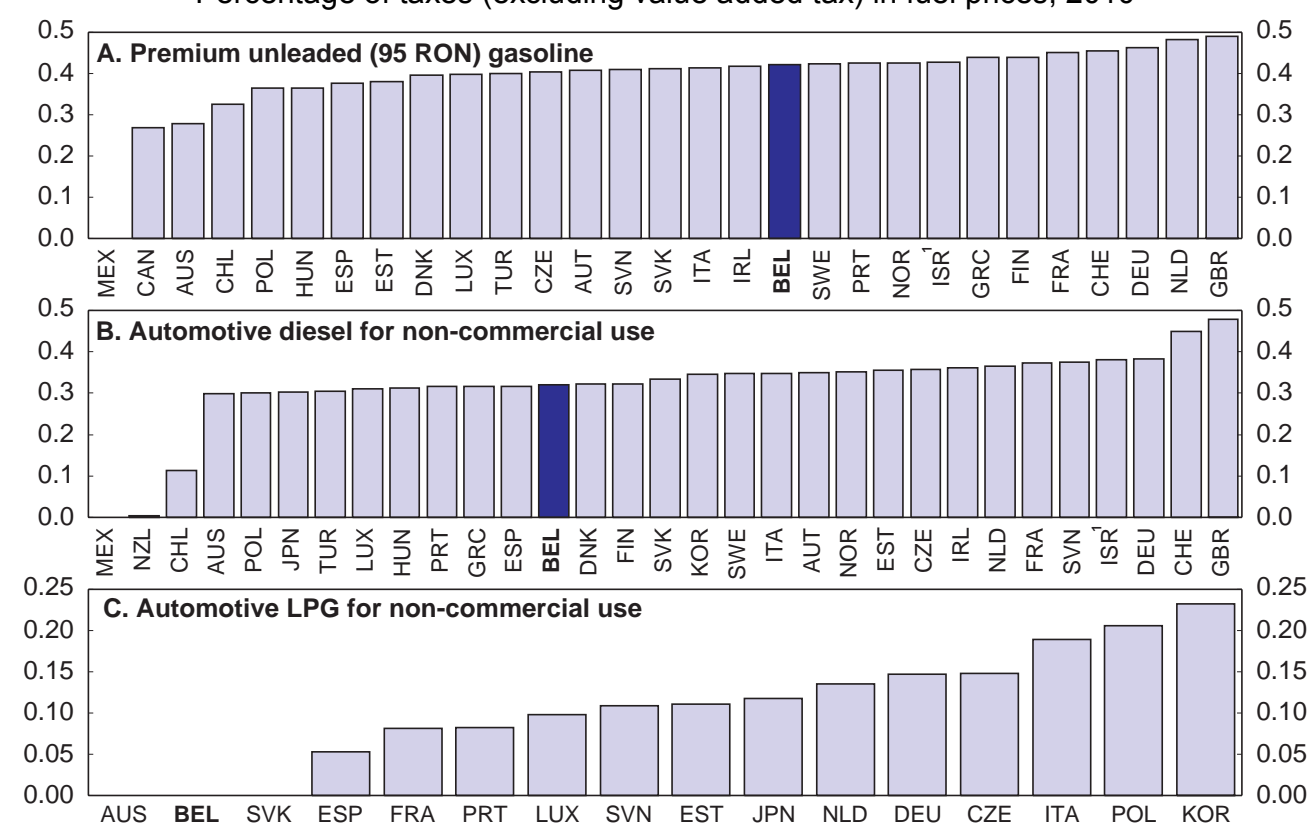

1. The statistical data for Israel are supplied by and under the responsibility of the relevant Israeli authorities. The use of such data by the OECD is without prejudice to the status of the Golan Heights, East Jerusalem and Israeli settlements in the West Bank under the terms of international law.

Source: OECD (2011), Energy Prices and Taxes, Vol. 2011/1. 
Additional incentives for car use and ownership arise from the tax treatment of company cars and purchase subsidies for "environmentally friendly" vehicles. ${ }^{11}$ Company cars provided by employers are strongly encouraged. Private use is treated as a lump sum in-kind benefit, with the taxable value between EUR 630 and EUR 2400 per year depending on emission class. As a result, employers have been treating company cars as cheap non-wage compensation cost and the number of company cars is estimated at $22 \%$ of the passenger car fleet, of which a third are considered as in-kind benefits (Mossakowski, 2011). The cars are often provided with a so-called fuel card, a benefit which effectively facilitates the treatment of fuel expenditures as company costs. Over the past years, the federal government made steps to green the company car fleet by linking fiscal deductibility of the cars to their $\mathrm{CO}_{2}$ emissions and, in 2010, reducing the deductibility of fuel cards to $75 \%$. These measures should have positive environmental effects, but do not go far enough to repair the damage done by underpriced car use. The tax treatment of such in-kind benefits should be the same as of standard income.

The federal government also encourages the purchase of low-emission vehicles through a tax rebate of $15 \%$ or $3 \%$ of the price for cars with $\mathrm{CO}_{2}$ emissions below $105 \mathrm{~g} / \mathrm{km}$ and $115 \mathrm{~g} / \mathrm{km}$ respectively. ${ }^{12}$ Intended to green the car fleet, the bonus also encourages the purchase of small diesel cars aggravating the problem of $\mathrm{NO}_{\mathrm{x}}$ and particulate emissions in city centres, while its abatement cost is rather high - EUR 446 and EUR 817 per tonne of $\mathrm{CO}_{2}$ for the two categories respectively (HCF, 2009). In the Walloon region, the effects are amplified by an environmental bonus/malus system for car purchase. At the same time, car purchase and annual ownership taxes seem to be among the least discriminatory with respect to $\mathrm{CO}_{2}$ across EU countries (see Braathen, 2011 for a comparison of Walloon numbers with other EU countries). All such subsidies have a high deadweight cost, as they are also given to people who would opt for a low-emission car anyway, a high fiscal cost (over EUR 200 million in 2010) and should be scrapped. The objective of greening transport should be pursued through marginal externality taxation of fuels, in particular a carbon $\operatorname{tax}\left(\right.$ see below). ${ }^{13}$

The federal government supports commuting through relatively complicated and generous commuting allowances which lower the marginal costs of travelling to work by all modes of transport (Table 3). Particular benefits concern public transport and collective transport and no distance limits are imposed on car travel. The system provides disincentives for moving closer to the workplace. Hence, the commuting allowance, particularly for road transport, should be either targeted to low-income workers, who otherwise risk falling out of the labour market, or replaced by a lump sum subsidy for such groups.

11. Ownership taxes (registration and annual road tax) are moderate relative to other EU countries. Registration and annual road tax are based related to the engine size and power (so-called fiscal power). Even for very polluting cars the registration tax falls with age.

12. The federal rebate is limited to EUR 4500 per car. The total cost of the measure in 2010 was EUR 208 million (double that of 2009) - on average almost EUR 2000 per car. Given the limited availability of cars with low emissions, a large share of the rebate may be pocketed by the producers (HCF, 2009).

13. To the extent there may be an overall case for encouraging the purchase of more fuel-efficient vehicles, as consumers may tend to undervalue the (far-in - the-future) fuel savings relative to purchase costs (OECD, $2009 \mathrm{~b}$ ) - this can be done through purchase taxation (or registration fees) rather than subsidies. 
Table 3. There is a wide range of allowances to support commuting ${ }^{1}$

\begin{tabular}{l|l}
\hline \multicolumn{1}{c}{ Lump sum benefits } & \multicolumn{1}{c}{ DUBLIC TRANSPORT } \\
\hline $\begin{array}{l}\text { The total cost refunded by the employer is treated as non- } \\
\text { taxable income. }\end{array}$ & $\begin{array}{l}\text { The employee can receive 0.15 EUR/km as non- } \\
\text { taxable income (home-work distance limited to 100 km } \\
\text { per day). Employers can deduct 100\% from CIT. }\end{array}$ \\
$\begin{array}{l}\text { The employer can treat this as a cost (100\% deductible from } \\
\text { CIT). }\end{array}$ & $\begin{array}{l}\text { A 20\% subsidy on the ticket price if the employer pays the } \\
\text { rest (100\% for civil servants). }\end{array}$ \\
\hline \multicolumn{1}{c}{ COLLECTIVE TRANSPORT (ORGANISED BY EMPLOYER) } \\
\hline $\begin{array}{l}\text { Non-taxable income up to the price of a first class train ticket } \\
\text { on the home-work route. }\end{array}$ & $\begin{array}{l}\text { The employee can receive 0.15 EUR/km as non- } \\
\text { taxable income (home-work distance limited to 100 km } \\
\text { per day). Employers can deduct 120\% of costs } \\
\text { from CIT. }\end{array}$ \\
\begin{tabular}{l} 
Employer can deduct 120\% of costs from CIT. \\
\hline
\end{tabular} \\
$\begin{array}{l}\text { A fixed non-taxable benefit of EUR 350 per year to cover the } \\
\text { costs of commuting. Employer can deduct 100\% from CIT. }\end{array}$ & $\begin{array}{l}\text { Employee can receive 0.15 EUR/km as non-taxable } \\
\text { income (no limit on the home-work distance). } \\
\text { Employer can deduct 100\% from CIT. }\end{array}$ \\
\hline $\begin{array}{l}\text { A fixed non-taxable benefit of EUR 350 per year } \\
\text { Employer can deduct 100\% from CIT. }\end{array}$ & $\begin{array}{l}\text { The employee can receive 0.2 EUR/km as non- } \\
\text { taxable income. He can also receive a bicycle or } \\
\text { a refund of bicycle costs. Employers can } \\
\text { deduct 120\% costs from CIT. }\end{array}$ \\
\hline
\end{tabular}

1. The employers and employees have to choose between the distance-based and the lump-sum allowances.

Source: High Council of Finance (2009) and Federal Government.

Public transport and bicycles are encouraged through tax benefits and other direct and indirect subsidies (reduced VAT, fuel tax exemption for public transport). The government refunds $20 \%$ of the commuting cost if the employer pays the rest. Despite this, only about $9 \%$ of Flemish and Walloon residents use public transport for commuting (the share is about $50 \%$ for Brussels residents), reflecting that public transport lacks flexibility to substitute the car on a wider basis (SPF Mobility, 2010). One factor may be that public bus transport is organised by a separate body in each of the regions and trains are the competence of a federal body, making co-ordination complicated. Moreover, at the regional level, land regulation issues and financing issues play a role, as for instance visible in the lagging setup of the regional express rail for Brussels.

The limited ability of public transport to adapt to changes in demand, points to the need for flexibility and more competitive pressure. More co-ordination among the regional and local governments is a must and bus schedules and routes should be made more flexible to accommodate demand. Tendering of services, currently used to a limited extent in Flanders, should be encouraged. Operators should be able to propose new routes, and entry barriers need to be lowered, by guaranteeing access to infrastructure. Ticket prices should remain regulated, due to the limited scope for competition, but subsidies should be transparent and follow a clearly identified benefit (e.g. mobility, equity, urban reasons). The government wishing to impose obligations (e.g. free tickets for elderly) should pay the full cost directly. Finally, in order to green public transport by improving load factors, more flexibility should be coupled with exposing operators to price signals to encourage emission reductions - they should pay the full (external) costs of their activity (e.g. fuel taxes). 


\section{External costs can be internalised through fuel taxation and a congestion charge}

Fuel taxation is generally well below the external costs generated by road transport, encouraging the demand for transport and relatively high fuel consumption (McKinsey, 2009). As in most countries, fuel taxation is generally higher than most estimates of marginal environmental externalities generated by transport. However, the costs incurred by transport through fuel taxation are disproportionately large for gasoline powered passenger cars, compared to diesel powered cars and in particular freight vehicles. This is largely due to lower relative taxation of diesel, which is associated with external costs of a magnitude higher than gasoline, mainly due to $\mathrm{NO}_{\mathrm{x}}$ and $\mathrm{PM}_{\mathrm{x}}$ emissions. Moreover, if the non-environmental externalities, such as road wear and tear, accident costs and in particular congestion, are taken into account, fuel taxation appears too low, in particular for freight. Both of these arguments are strengthened in Belgium by the low taxation of diesel (see CE Delft, 2008, Koźluk, 2010, for international examples and Hertveldt et al., 2009, for a Belgian specific study). The arguments against higher fuel taxation are mainly related to competitiveness (of the freight sector and the port of Antwerp) and fiscal revenue leakage. Low taxation of diesel diminishes the incentives provided by the government subsidies for shifting freight from road to rail and inland waterways (IWW). At the same time, empirical analysis generally fails to find evidence of a significant effect of changes in fuel prices relative to neighbouring countries on fiscal revenues (Schmitz, 2011), though the importance of international traffic means that a substantial unilateral increase is sure to have some consequences. Nevertheless, the overall effects of higher fuel prices on fuel consumption are likely to be limited in the short to medium term - estimates show that a $1 \%$ increase in fuel prices would lead to about a $0.2-0.3 \%$ decrease in fuel demand (Schmitz, 2011). Long-term effects are likely to be higher as car owners switch to more fuel efficient vehicles (Goodwin et al., 2004).

Fuel taxation should be adjusted in line with the marginal externalities - the users who emit pollutants should pay the marginal costs of their activity, so that they face the adequate incentives to reduce pollution. This means primarily increasing the relative taxation of the more polluting diesel, which should reduce the Belgian diesel bias, thereby lowering $\mathrm{NO}_{\mathrm{x}}$ and particulate emissions. Such a reform was recommended in the 2009 Survey, and the federal government made a step in this direction by increasing the excise on diesel in 2010. To boost the effectiveness of price-related measures, Belgium-specific price regulations should be scrapped: the price cap on automotive fuels, the automatic adjustment of excise taxes to accommodate large fuel price changes (inverse cliquet) and special refund of part of the excise tax for vans, buses, taxis and trucks (professional diesel).

A particular externality of road transport is congestion. The estimates of the cost of congestion in Belgium range from $0.05 \%$ of GDP (Hoornaert et al., 2009) to $2 \%$ of GDP (INFRAS, 2004), largely concentrated in bottlenecks around Brussels and Antwerp. An efficient instrument to tackle this issue, in particular given the concentrated nature of congestion in Belgium, is a congestion charge for each kilometre driven in bottleneck areas and times (Fosgerau and Van Dender, 2010; Eliasson, 2010) or a simpler version such as city access charges (urban tolls) introduced in several cities in the OECD (e.g. London, Oslo, Stockholm). Such charges are well targeted to deal with local problems at a limited overall cost. A congestion charge is likely to be a viable solution to the traffic problems of Brussels, reducing queues, travel time and improving air quality, but its introduction encounters a major obstacle due to the regional division of powers in transport policies, as the outer ring road passes through Wallonia and Flanders.

\section{Road pricing can be a viable solution}

A more comprehensive, if ambitious, solution would be a nation-wide GPS-based road charge, such as the system recently proposed in the Netherlands (Koźluk, 2010). ${ }^{14}$ Such a scheme should include a

14. In late 2009 the Dutch government (unsuccessfully) attempted to introduce a road pricing scheme to cover all roads and (almost) all vehicles, moving away from fixed vehicle taxation (registration and annual ownership taxes) to a user-pays system of charging road transport. A fixed vehicle-related per-kilometre 
per-kilometre charge linked to the externalities generated by different categories of vehicles and a congestion surcharge in bottleneck areas. The system could bring about substantial reductions in GHG emissions from transport and air pollutants while limiting the negative impact on economic activity (for instance, contrary to fuel taxation road pricing does not discriminate between domestic transport services and transit transport, and does not encourage fuelling up abroad). If the externalities linked to fuel consumption (such as $\mathrm{CO}_{2}$ ) would be embodied in fuel taxes, the per-kilometre prices could take care of the other externalities, in particular those linked to the driven distance (e.g. road wear and tear), discriminating by category of vehicle. The price-discrimination across categories would also improve the $\mathrm{NO}_{\mathrm{x}}$ and particulate emission performance (Box 3). It could first be rolled out for freight (as in Germany and Slovakia) and utility vehicles, as this is likely to be more politically feasible. For the same reason, road pricing in Belgium might first apply to company cars, and as the scheme gains more public acceptance, it can subsequently be extended to all traffic.

In 2011, the three regions agreed on introducing a common GPS-based per-kilometre road charge for freight, though at the moment of writing details were not available. Such a system can only be efficient if introduced uniformly across the country, and even more so, if introduced across neighbouring countries. Moreover, when introduced for passenger transport, road pricing or congestion charges are likely to increase the demand for public transport, in particular in peak hours, raising the importance of making services more responsive to demand.

\section{Household energy efficiency is poor due to weak incentives}

The housing stock is poorly insulated (Table 4), contributing to household energy use (per square metre) $70 \%$ above the EU average (twice that in the neighbouring Netherlands) and residential emissions per capita twice the OECD average (Table 5 and McKinsey, 2009). A third of the housing stock pre-dates 1945 (particularly in Brussels and Wallonia) and heating systems tend to be old (HCF, 2009). Noncompliance with building norms means that the problems are not limited to old buildings (OECD, 2007a). Given the relatively high prices of electricity (Koźluk, 2009), the main source of household heating is natural gas. Heating oil, roughly a third more emission-intensive than gas $\left(\mathrm{CO}_{2}\right.$ per GJ), plays an important role (half of the energy use in Wallonia, a third in Flanders and Brussels).

Table 4. House insulation is poor across regions

As a percentage of total

\begin{tabular}{|c|c|c|c|c|c|c|}
\hline & $\begin{array}{c}\text { Double-glazed } \\
\text { windows }\end{array}$ & $\begin{array}{c}\text { Roof } \\
\text { insulation }\end{array}$ & $\begin{array}{c}\text { Wall } \\
\text { insulation }\end{array}$ & $\begin{array}{l}\text { Piping } \\
\text { insulation }\end{array}$ & $\begin{array}{l}\text { Ground } \\
\text { insulation }\end{array}$ & $\begin{array}{c}\text { Heat } \\
\text { reflectors for } \\
\text { heaters }\end{array}$ \\
\hline \multicolumn{7}{|c|}{ Flanders (2005), of a total of 2.5 million housing units } \\
\hline Complete & 66.4 & 65 & 40.5 & 49.5 & 22.8 & 8.7 \\
\hline Incomplete & 17.2 & 7.9 & 10.6 & 17.3 & 8.2 & 7.1 \\
\hline Non-existent & 16.4 & 30.1 & 48.9 & 33.1 & 69 & 84.1 \\
\hline \multicolumn{7}{|c|}{ Wallonia (2007), from a total of 1.3 million housing units } \\
\hline Non-existent & 19.1 & 37 & 64.1 & n.a. & n.a. & n.a. \\
\hline \multicolumn{7}{|c|}{ Brussels-Capital (2005), from a total of 400 thousand housing units } \\
\hline $\begin{array}{l}\text { Non-existent } \\
\text { Unknown state }\end{array}$ & $\begin{array}{l}34.1 \\
6.4 \\
\end{array}$ & $\begin{array}{l}18 \\
50.9\end{array}$ & $\begin{array}{l}29.4 \\
55.2 \\
\end{array}$ & $\begin{array}{l}19.2 \\
56.7\end{array}$ & $\begin{array}{l}\text { n.a. } \\
\text { n.a. }\end{array}$ & $\begin{array}{l}\text { n.a. } \\
\text { n.a. }\end{array}$ \\
\hline
\end{tabular}

Source: Heylen et al. (2007) and Carlier et al. (2007) and De Coninck and Verbeeck (2005).

charge was to be combined with a congestion fee, applicable during peak periods in congested areas. By 2020 the scheme was to bring significant benefits in terms of traffic and the environment, with expectations of a mildly positive effect on GDP. Technical solutions were based on fitting vehicles with an onboard device using GPS technology to track travelled distance and relay the information via GSM technology to the operator. The latter would issue a monthly bill to the vehicle owner, with information restricted for privacy reasons. The roll-out was to start with freight in 2012 and cover passenger vehicles by 2017. 
ECO/WKP(2011)63

Table 5. Residential emission intensity

Emissions per capita are expressed in $\mathrm{kg}$ of $\mathrm{CO} 2$ equivalent

\begin{tabular}{|c|c|c|}
\hline & $\begin{array}{l}\text { Residential emissions per capita } \\
(2007)\end{array}$ & $\begin{array}{l}\text { Residential emissions per square } \\
\text { meter of useful floor area (2002) }\end{array}$ \\
\hline Belgium & 1786 & 62 \\
\hline Germany & 1055 & 36 \\
\hline France & 956 & 24 \\
\hline Netherlands & 997 & 29 \\
\hline Spain & 429 & 14 \\
\hline Italy & 861 & 20 \\
\hline United Kingdom & 1261 & 38 \\
\hline OECD $^{1}$ & 900 & n.a. \\
\hline OECD EU & 911 & n.a. \\
\hline OECD North America ${ }^{2}$ & 1163 & n.a. \\
\hline OECD Pacific ${ }^{3}$ & 474 & n.a. \\
\hline
\end{tabular}

1. Excluding Mexico and Korea.

2. Excluding Mexico.

3. Excluding Korea.

Source: United Nations Framework Convention on Climate Change Database and Eurostat.

\section{Household energy policies - too much of a good thing}

Energy prices are not providing adequate incentives to increase energy efficiency of housing, in part due to the widespread use of social energy policies (Box 4) and, to a smaller extent, employer-provided in-kind benefits. As lower energy tariffs discourage energy saving, they should be scrapped, while social objectives should be pursued through social policies, such as a lump-sum income subsidy targeted at lowincome households, coupled with measures to increase the accessibility of energy-efficiency investments for such groups (see below). Another group not directly exposed to energy prices are those subject to the in-kind benefit, whereby the employer pays the electricity and heating bills. Such benefits are taxed as a lump-sum, regardless of the actual amount, ${ }^{15}$ making them a cheap non-wage benefit. These benefits have negative environmental effects as concerned households face zero marginal costs of energy and are more likely to benefit higher income groups. Such benefits should be taxed as any other wage income.

\section{Box 4. Social energy policies and the incentives for saving energy}

Heating affordability for low-income households is guaranteed through the Social Heating Fund - a lump sum subsidy of up to EUR 300 per year (heating oil and natural gas bill). In addition, there is the so-called social energy (electricity and gas) tariff, equal to the lowest commercial (i.e. industry) tariff in the area and available to almost $7 \%$ (electricity) and over $5 \%$ (gas) of households. Since 2009, the attribution of social tariffs became automatic. Households eligible for social tariffs are also exempt from the federal surcharge on energy and face a price that can be well below half of the market tariff, hence providing much lower marginal incentives to save energy.

The reduced VAT rate $(12 \%)$ on coal for households can also be regarded as a social policy, given that low-income households are the most likely to be heated with coal. Despite a large decrease, coal still heats some $2 \%$ of households in Flanders, and the lower VAT effectively decreases the incentives to change to alternative fuels.

In Flanders, all households are eligible for a free electricity quota for each household member. This may further decrease the saving incentive for households eligible for social tariffs (by reducing the total energy bill), but the effect on other households is unclear. The free quota has to be incorporated into retailers' pricing strategies and hence forces a higher tariff on the remaining consumption - potentially increasing the incentive to save.

15. The employer pays the annual bills, and the employees are taxes as if they received a lump sum income of EUR 370 in case of electricity, EUR 740 for heating. In case of management personnel the amount subject to taxation is twice as high. This amount has been increasing fairly rapidly in the recent years. 
To counter the weak energy saving incentives and promote energy efficiency, the governments have stepped up measures to directly encourage investment in improvement of housing. The federal government offers numerous tax reductions (e.g. for the replacement or improvement of boilers, windows, insulation of roofs, walls and ceilings, energy-saving devices, installation of heat pumps, solar heaters and solar panels) of up to EUR 2650 per household per year (40\% of expenses). The regions top these up by a multitude of subsidies: 22 in Wallonia (down from 48 in 2009), 20 in Brussels and 18 in Flanders, some of which are decided upon an annual basis.

The focus on energy efficiency improvements is commendable, in particular given the 20/20/20 objectives, but the actual outcomes are rather disappointing (HCF, 2009). One reason is that government measures tend to pick "winning" technologies, disregarding the relative cost efficiency and despite the explicit advice from government-financed energy audits of households. The lowest subsidies are provided for measures most efficient in energy saving: roof, wall and ground insulation, window replacement (Renard,2008 and De Coninck and Verbeeck, 2006). A simple calculation based on 2008 data shows that due to federal and regional fiscal incentives, a Walloon homeowner would choose to install photovoltaic panels (PV) over wall insulation, where the latter would be six times more cost-efficient in reducing $\mathrm{CO}_{2}$ (Spies and Buxant, 2008). The cost of $\mathrm{CO}_{2}$ avoidance for the taxpayer would be EUR 23 per tonne in the case of wall insulation, but EUR 1600 for PV, with similar outcomes in the other regions. Notably, the situation in Wallonia itself has improved somewhat, due to the reforms of Walloon measures, including scrapping of some of the regional subsidies to PV The strong public support for PV resulted in increasing take up in 2010, but is questionable given the climate conditions and no cost/benefit assessment of the policies (IEA, 2010). Similarly, fiscal incentives support both the replacement of old boilers as well as their maintenance. Most old boilers are subject to quasi-mandatory replacement (because of government or insurance norms), implying an effective subsidy to comply. ${ }^{16}$ Finally, many existing subsidies concern also new housing, where measures could be implemented more effectively through stricter building standards.

The incentives for insulation are more complicated for rented housing, which constitutes roughly a quarter of Belgian housing. Tenants are likely to be less willing to invest in energy improvements of their housing, not being able to reclaim the full benefits from the investment. Similarly, owners of rented property have limited possibility to recuperate the cost of the investment because of rent regulation. In principle, rent regulation foresees a phased-in increase of the rent due to an increase in property value (for instance due to an investment in energy efficiency). Still, the quality and energy efficiency of rented property remains rather poor, and a reviewing rent regulation in this respect, to introduce stronger incentives, should be considered. ${ }^{17}$

\section{Price signals provide the most straightforward incentives, while awareness could be improved,}

The importance of nuclear energy in providing base load electricity capacity means that base load is relatively $\mathrm{CO}_{2}$-free compared with gas- and coal-powered peak load. This distinction may not be straightforward in a unified EU energy market, but due to capacity constraints on the Belgian international connection grid, it is possible to assume that peak load is largely supplied by local producers. Hence, the

16. HCF also noted that given the very limited competition in many of the subsidised areas (e.g. energy audits, installation of equipment) suppliers are likely to take over a large part of the subsidy - reducing the effect on households' behaviour. Moreover, the division of powers obstructs the flow of these services - licenses for installation of facilities (e.g. PV) and audits issued in one region are not recognised in the other.

17. For example in Wallonia, $70 \%$ of owner occupied housing and only $50 \%$ of rented housing is classified as good or very good standard (Carlier et al., 2007). 
governments also aim at smoothing electricity consumption, particularly through the 24-hour day. This can be done by encouraging meters with day/night tariff readings or the more costly so-called smart meters with real time readings. The Flemish government is planning smart metering by 2018, while tests are underway in Wallonia. As emphasised, such measures will not affect $\mathrm{CO}_{2}$ emissions in the EU, as long as the ETS cap remains unchanged (Box 1).

Households' energy efficiency awareness is poor. The data for Brussels reveals that many households are unaware of the state of insulation of their houses and thus is unlikely to take up subsidies (of which many households have not heard) or in general to improve the energy efficiency of housing (Table 4). ${ }^{18}$ The rental and secondary markets are also likely to suffer from the asymmetry of information, if the owners do not reveal the energy efficiency of houses put on the market. The governments have recently taken steps to reduce asymmetry by increasing energy awareness by making energy certificates (PEB) an obligatory document for the placement of houses on the market. Other measures include labelling of products (e.g. domestic appliances) but arguably, households' incentives would increase with the energy price.

Overall, the existing subsidies for energy saving should be scrapped and the incentives should be provided through energy prices. Government policies should focus on fixing market failures in the areas where efficiency can be improved in economically viable ways:

- Internalising the costs of externalities associated with energy use into the prices (through an externality tax, such as a carbon tax on heating fuels).

- Reducing uncertainty for investments which are likely to break-even in years, by providing credible paths for externality taxation.

- Supporting liquidity constrained low-income households to make such investments, (through targeted investment subsidies or cheap loans) to exploit relatively cheap abatement possibilities, as low-income households are likely to live in poorly insulated housing. In this line, the federal government has recently set aside funds to promote third-party financing and cheap loans for energy efficiency improvements of low-income households (FRCE/FRGE), while the regions are providing cheap loans.

- Improving energy-efficiency awareness.

- Enforcing minimum building standards for new housing.

Notably, a number of the measures proposed above will also encourage more cost-efficient abatement in the remainder of the non-ETS segment: small industry, services and agriculture.

\section{Purchasing emission rights abroad may slow adjustment to a less carbon-intensive economy}

The national burden-sharing agreement foresees that the federal government offsets emissions purchasing carbon credits through Kyoto flexible mechanisms (Table 1). Almost half of the overall amount of carbon credits for 2008-12 has already been delivered by mid-2011 (of which a third through emission rights purchases and two-thirds through projects reducing $\mathrm{CO}_{2}$ emissions in developing countries). The carbon prices paid are confidential. As mentioned, regions can also use flexible mechanisms. Such investments are a viable Kyoto tool that encourages emission reductions in developing countries, where they are likely to be cheaper. However, there is a risk that the strategy may be short-sighted. Such

18. Part of is be due to Brussels-specific reasons - an urban character of housing (more blocks of flats), more rented housing and more social tariff benefiters. Data for Flanders show that just above half of survey respondents heard of the federal tax reductions, most of them in the higher income groups (Cour des Comptes, 2009). 
purchases are financed through the federal surcharge on energy which is subject to a reduction for large users, effectively shielding large emitters from external costs at the expense of small users. The result is reduced incentives for restructuring towards a less polluting technology mix and "green" R\&D, which may delay the necessary adjustment to a less carbon intensive economy.

\section{Polluters must face the marginal cost of damages to ensure cost-efficient abatement}

Environmental taxation is used far less than in other OECD countries (Figure 10). Fossil fuels taxes are among the lowest in Europe (Table 6) resulting in a very low implicit $\mathrm{CO}_{2}$ prices (Table 7) and a higher than optimal use of fuels, likely skewing the production mix from labour to energy and dampening incentives for energy-saving and environmentally friendly $R \& D$. Only taxation in the category pollution/resources (for instance land-fill taxes and packaging waste, Box 5) is above that in most EU countries.

Figure 10. Environmentally-related tax revenue

2009

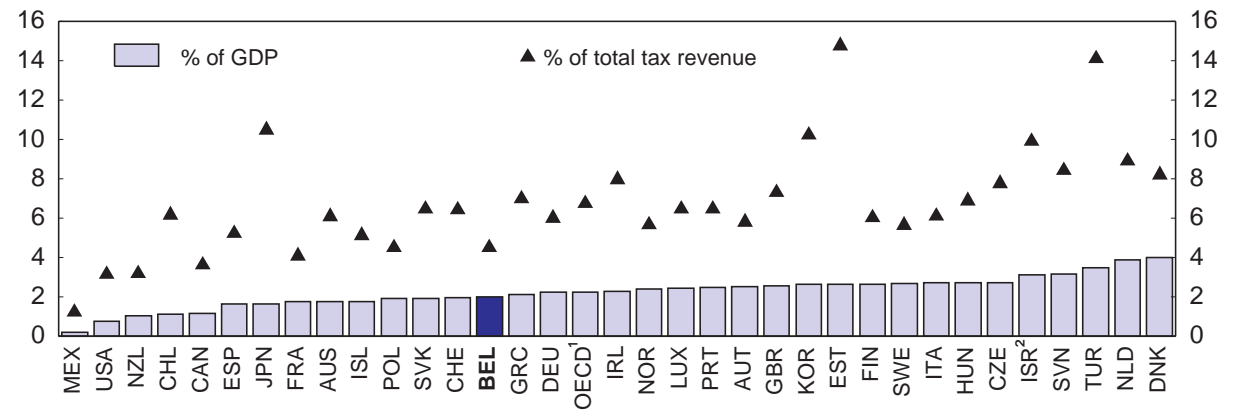

1. The OECD aggregate is a simple average.

2. The statistical data for Israel are supplied by and under the responsibility of the relevant Israeli authorities. The use of such data by the OECD is without prejudice to the status of the Golan Heights, East Jerusalem and Israeli settlements in the West Bank under the terms of international law.

Source: OECD/European Environment Agency Database on instruments used for environmental policy and natural resources management, www.oecd.org/env/policies/database.

Table 6. Revenues from environmental taxes are low

\begin{tabular}{|c|c|c|c|c|c|c|c|c|c|c|}
\hline & \multicolumn{10}{|c|}{ Environmental taxes (total, 2008) } \\
\hline & \multirow[b]{2}{*}{$\begin{array}{c}\% \\
\text { GDP }\end{array}$} & \multirow[b]{2}{*}{$\begin{array}{c}\% \text { tax } \\
\text { revenue }\end{array}$} & \multicolumn{2}{|c|}{ Energy taxes } & \multicolumn{2}{|c|}{$\begin{array}{l}\text { Of which transport } \\
\text { fuel taxes }\end{array}$} & \multicolumn{2}{|c|}{$\begin{array}{l}\text { Transport taxes } \\
\text { (excl. fuels) }\end{array}$} & \multicolumn{2}{|c|}{$\begin{array}{l}\text { Pollution/ } \\
\text { Resources }\end{array}$} \\
\hline & & & $\begin{array}{c}\% \\
\text { GDP }\end{array}$ & $\begin{array}{l}\% \text { tax } \\
\text { revenue }\end{array}$ & $\stackrel{\%}{\mathrm{GDP}}$ & $\begin{array}{l}\% \text { tax } \\
\text { revenue }\end{array}$ & $\begin{array}{l}\% \\
\text { GDP }\end{array}$ & $\begin{array}{c}\% \text { tax } \\
\text { revenue }\end{array}$ & $\begin{array}{c}\% \\
\text { GDP }\end{array}$ & $\begin{array}{l}\% \text { tax } \\
\text { revenue }\end{array}$ \\
\hline \multirow{2}{*}{$\begin{array}{l}\text { Belgium } \\
\text { rank in OECD-EU, } \\
\text { highest to lowest }\end{array}$} & 2.0 & 4.4 & 1.2 & 2.8 & 1.1 & 2.5 & 0.6 & 1.3 & 0.1 & 0.3 \\
\hline & $19 / 20$ & $20 / 20$ & $19 / 20$ & $20 / 20$ & $17 / 20$ & $18 / 20$ & $10 / 20$ & $11 / 20$ & $5 / 20$ & $5 / 20$ \\
\hline Germany & 2.2 & 5.7 & 1.8 & 4.7 & 1.4 & 3.6 & 0.4 & 0.9 & 0.0 & 0.1 \\
\hline Netherlands & 3.9 & 9.9 & 1.9 & 4.9 & 1.2 & 3.2 & 1.3 & 3.3 & 0.6 & 1.7 \\
\hline France & 2.1 & 4.9 & 1.4 & 3.3 & 1.2 & 2.8 & 0.6 & 1.3 & 0.1 & 0.2 \\
\hline United Kingdom & 2.4 & 6.5 & 1.8 & 4.8 & 1.7 & 4.5 & 0.5 & 1.4 & 0.1 & 0.2 \\
\hline $\begin{array}{l}\text { Denmark, Sweden, } \\
\text { Finland (avg.) }\end{array}$ & 3.7 & 8.0 & 2.0 & 4.4 & 1.2 & 2.6 & 1.1 & 2.3 & 0.6 & 1.3 \\
\hline \multirow{2}{*}{$\begin{array}{l}\text { OECD-EU } \\
\text { Norway, Iceland } \\
\text { (average) }\end{array}$} & 2.6 & 6.8 & 1.8 & 4.8 & 1.2 & 2.7 & 0.6 & 1.6 & 0.2 & 0.4 \\
\hline & 2.2 & 5.6 & 1.1 & 2.8 & n. a. & n. a. & 0.9 & 2.1 & 0.2 & 0.6 \\
\hline
\end{tabular}

Source: European Commission (2010), "Taxation trends in the European Union: Data for the EU Member States, Iceland and Norway". 
Table 7. The implicit price of $\mathrm{CO}_{2}$ for different fuels and uses varies widely

Based on excise tax, 2008

\begin{tabular}{|c|c|c|}
\hline Fuel & Use & Implicit price of tonne of $\mathrm{CO}_{2}$ (EUR) \\
\hline \multicolumn{2}{|c|}{ Unleaded gasoline } & 262.7 \\
\hline \multirow[t]{2}{*}{ Diesel } & Used as motor fuel & 116.6 \\
\hline & $\begin{array}{l}\text { Other use (e.g. industrial and } \\
\text { heating) }\end{array}$ & $6.8-7.7$ \\
\hline \multirow[t]{2}{*}{ Kerosene oil } & Used as motor fuel & 232 \\
\hline & $\begin{array}{l}\text { Other use e.g. industrial, } \\
\text { heating) }\end{array}$ & $7.2-8.4$ \\
\hline Heavy oil & Commercial and private use & 4.9 \\
\hline \multirow{2}{*}{$\begin{array}{l}\text { LPG, propane } \\
\text { and butane }\end{array}$} & Used as motor fuel & 0 \\
\hline & $\begin{array}{l}\text { Other use (industrial and } \\
\text { private) }\end{array}$ & $5.9-14.1$ \\
\hline \multirow[t]{3}{*}{ Natural gas } & Used as motor fuel & 0 \\
\hline & Industrial and commercial use & 0 \\
\hline & $\begin{array}{l}\text { Combustion (commercial and } \\
\text { private use) }\end{array}$ & $1.8-4.9$ (0 for large consumers) \\
\hline \multirow[t]{2}{*}{ Coal and coke } & Commercial use & 5.2 \\
\hline & Private use & 0 \\
\hline \multirow[t]{2}{*}{ Electricity } & Commercial use & 8.3 \\
\hline & Private use & 8.3 \\
\hline \multicolumn{2}{|c|}{ EU ETS price, 2008 average } & 15 \\
\hline
\end{tabular}

1. The implicit price of $\mathrm{CO}_{2}$ is calculated as the total excise duty on a given fuel divided by its $\mathrm{CO}_{2}$ intensity.

Source: High Council of Finance (2009).

\section{Box 5. Eco-taxes - limited environmental effect so far}

The eco-tax law (1993) introduced product taxes to discourage consumption of certain (environmentally harmful) goods by encouraging a switch to less harmful substitutes; hence in principle the taxes were to yield minimal revenues. The law included a first list of products subject to eco-taxation while further decisions were left to a committee of experts established for this purpose. The proposed products were drink containers, some types of industrial packaging, some disposable products (disposable razors till 1997 and cameras), batteries, pesticides (abolished in 2001) and paper. Most products would be exempt if a collection and recycling scheme was organised.

The main problems with these eco-taxes concern industry opposition to placing individual products on the list, the lack of transparency and clarity of the motivation and the exclusion of major users of pesticides (agriculture) from taxation. As a result, the goods subject to eco-taxes were mainly marginal yielding doubtful environmental gains. Few products added to the list in due course: disposable plastic crockery, plastic bags, and containers of ink, glue and solvent for professional use. The revenue from the eco-taxes is indeed negligible (EUR 0.2 million in 2010) aside the tax on drink containers (EUR 200 million).

\section{A country-wide carbon tax would reduce emissions and improve energy efficiency}

Increasing the overall taxation of energy should bring about a cost-efficient reduction in emissions. Well-designed energy taxation would entail pricing the associated emissions (or generally, pollution), thereby giving polluters the appropriate and straightforward incentives to reduce harmful activity in a cost-effective way (Box 6). This should be achieved by realigning excise taxes and introducing a carbon tax on fuels. Current excise taxes on fuels have no relation to the environmental externalities - the implicit carbon prices differ vastly among fuels and among different uses of the same fuel (Table 7). Greater 
neutrality should be introduced if the associated externalities do not differ too widely (there may be a special case for transport fuels, see above). To ensure efficient abatement at minimum cost marginal externalities should be built into prices. In particular, GHG externalities should be addressed with a carbon price. As the ETS segment of the economy is de facto subject to a carbon price, a carbon tax should be introduced for the non-ETS segment of the economy (primarily transport and housing, but also small industry, services and agriculture), particularly as this is where emissions have been increasing over the past two decades. ${ }^{19}$ Given the high uncertainty about the optimal carbon price, the level of the carbon tax should be chosen with the aim of achieving the Belgian GHG 20/20/20 objective. ${ }^{20}$ In this light, the government should establish a clear, credible timetable for the carbon tax (with some adjustment possibilities) in order to provide sufficient incentives to invest in greener technologies and $\mathrm{R} \& \mathrm{D}$, as such investment is likely to break-even only over a long time frame. The new carbon tax may need to be adjusted to respect to EU guidelines, given recent EU Commission's proposals regarding changes in energy taxations (EC, 2011).

\section{Box 6. Cost-efficient "green" policies - polluters should face the marginal cost of externalities}

"Green-growth" policies should aim at overcoming the market failures arising from: the environment being a public good; the costs of monitoring and enforcement; imperfect or asymmetric information; and capital market imperfections (De Serres et al., 2010, Duval, 2008). The main principles for choosing instruments to reach climate change and environmental goals entail:

- equalising the marginal abatement cost across emission sources to ensure lowest-cost abatement;

- fostering an efficient level of innovation, in order to lower future abatement costs;

- coping effectively with future risks and uncertainties.

Putting a price on the pollution source or over-exploitation of a scarce resource should improve the competitive position of clean(er) technologies and goods and incentives to invest into green R\&D as the costs of pollution will be integrated in the final prices. Pricing externalities can be done, for example, through a cap-and-trade scheme or a polluter-pays (marginal) externality tax. In the presence of high monitoring and information costs, in particular when emission sources are small and numerous (such as in transport or residential heating), the taxation of proxies (i.e. fuels) can be a viable solution, conditional on a sufficiently robust link with the externality.

Externality taxation usually meets opposition on competitiveness grounds and, in the case of GHG emissions, because of the fear of carbon leakage. However, there is no obvious relation between environmental tax revenues and competitiveness (HCF, 2009) in particular within a co-ordinated EU approach. The ETS segment will face a carbon price by default, while the rest of the economy (mainly transport and residential) is less directly exposed to international competition. As all EU countries introduce measures to fulfil the 20/20/20 objectives, they impose a carbon price, explicit or implicit. The wider the coverage of a uniform carbon price, the more likely that emissions are reduced at the lowest cost. Carbon taxation will burden particularly heavy emission sources, but indeed this is the point of reorienting the economy to a greener path. A balance, though, must be found between a gradual introduction, which

19. During 1990-2009, Belgian non-ETS GHG emissions grew by $2.5 \%$, while ETS emissions fell by $21 \%$.

20. Establishing an optimal carbon price is subject to the enormous uncertainty surrounding the economic effects of GHG emissions and climate change, to materialize decades and centuries ahead. Meta-analyses show a vast range of estimates - a mean price of a tonne of $\mathrm{CO}_{2}$ from a survey of 232 estimates is around EUR 60 (2010 prices) and the median around EUR 30, with extreme values not being uncommon (Tol, 2009, Kuik et al, 2009). Simulations performed for Belgium show that achieving 2020 goals would require a carbon price of EUR 37 per tonne in the ETS segment and EUR 28 per tonne in the non-ETS segment (Bassiliere et al., 2008, adjusted to 2010 prices). 
gives polluters time for less abrupt adjustment, and an excessively long phase-in which would punish cleaner technologies and risk the failure of meeting international obligations.

At the moment, practically all Belgian ETS emission permits are grandfathered (granted for free based on historical emissions) providing windfall profits to heavy polluters. This should not prevent an efficient allocation of emission rights, as rights are tradable. However, it does imply transfers from energy consumers to producers. Moreover, empirical evidence show producers passing on the opportunity costs of holding $\mathrm{CO}_{2}$ permits (obtained for free) to the wholesale price in most EU countries (Sijm et al., 2008) and in particular in Belgium (CREG, 2008) where estimated windfall gains for electricity producers are in the area of $1 / 2$ per cent of GDP for 2005-07. Increasing the scope of auctioning would reduce windfall gains, yield revenue and improve the governments' experience in the auctioning system, but for the next few years the effects will remain minute under EU limits on auctioning. In this case, the federal government should consider fully taxing away the windfall profit gained from grandfathering of permits. ${ }^{21}$

A carbon tax would also encourage energy efficiency - currently promoted through tax reductions for industry, voluntary agreements and requirements on utility suppliers. The federal government grants higher corporate income tax deductions for energy-efficiency and green investments, while the regions revert to voluntary agreements. Flanders and Wallonia have signed agreements with enterprises covering over $90 \%$ of emissions, rewarding participants with tax benefits (such as exemptions from the federal excise tax on fossil fuels), exemptions from selected regulatory requirements and financial aid. Electricity suppliers have a public service obligation of saving energy (IEA, 2010) under which they are to achieve annual reductions in final consumers' energy use under the threat of a fine (Flanders and Brussels) or in return for a premium (Wallonia). None of the measures seem a first best solution in a national context: tax breaks (CIT and excise) come at a high fiscal cost, while voluntary agreements are generally unlikely to be very effective in reducing emissions (De Serres et al., 2010) in particular if lower energy prices are granted in return. Moreover, such measures may have undesirable effects on emissions if electricity (and gas) is substituted with e.g. heating oil. Appropriate energy saving incentives should come from a national carbon tax.

\section{Revenues from environmental taxation could be used to lower taxes on labour}

The revenues from environmental taxation can be used to reduce more growth-distorting taxation, such as on labour, aiding the transition from an energy-intensive economy and potentially preserving the competitiveness of Belgian companies (see for example Bassilière et al., 2009). A well-designed shift in the taxation burden from labour to energy would be likely to increase employment (Bassilière et al., 2005 and 2009) but admittedly, with automatic wage indexation (OECD, 2011a), this effect may be limited if the higher prices (due to environmental taxation, though potentially offset by lower labour costs) are translated into wage increases. Simple static calculations show that revenues equal to $10-15 \%$ of labour taxation could be obtained from a combination of: increasing environmental taxation to the EU average level; a carbon tax (non-ETS segment); and taxing away of windfall gains from free permits (ETS) and scrapping subsidies and tax reductions for transport, energy prices and energy-efficiency investments. Concerns about the regressive nature of environmental taxes (poorer households tend to have a higher share of energy in the consumption basket) could be addressed by focusing the reductions in labour taxation on the lower end of the income distribution. Still, many of the existing measures (in-kind benefits such as company cars, fuel cards, energy bills; energy efficiency subsidies) benefit mostly higher-income households; hence their scrapping could increase the progressivity of fiscal policies (HCF, 2009). Finally,

21. One of the concerns with electricity producers paying the price of $\mathrm{CO}_{2}$ emissions is that wholesale electricity prices are set reflecting the marginal price of the most expensive production site operating. The carbon price increases this marginal price and thus creates a windfall gain for nuclear producers. In principle, (part of) this profit can be taxed away, but in practice not for imported energy. 
higher revenues could also allow for more spending to improve the poor state of nature preservation (Box 7).

\section{Box 7. Environmental protection is costly, but should play a more important role}

The strong pressure on the environment comes from dense population, intensive industry, agriculture and transport. Land use reflects the high population density - residential and commercial services take up $19 \%$ of land use, second in the EU and two-and-a-half times the EU average. Industry and transport use $6 \%$ of land area, twice the EU average. Agriculture takes up 53\%, leaving little space for nature. Despite progress in the recent years, Belgium is the OECD country with the lowest surface of protected environmental areas per capita, and among the lowest in terms of protected areas relative to total surface (the first and so far only national park of 57 square km was opened in Flanders in 2006). The level of protection of these areas is generally lower than elsewhere. Together with years of extremely poor surface water quality this has contributed to a situation where the share of threatened species among indigenous fauna and flora are well above that in most OECD countries. The heavy implicit and explicit subsidies to agriculture and land use policies have placed Belgium among the handful of OECD countries where the share of forest land has not grown since 1990, reflecting in part poor take-up of EU agricultural land forestation programmes (OECD, 2007a).

Source: OECD Environmental Data Compendium, World Database on Protected Areas, UN Millennium Development Goal Indicators.

\section{Improvements in the area of water quality are visible, but suffer from a large backlog}

Significant attention was devoted to water quality in a previous environmental chapter (OECD, 2001), in part as the exploitation of water resources is among the most intensive in the EU. At the time, both surface and underground water quality were among the poorest in the EU, due to the effective lack of treatment of urban wastewater and very intensive agriculture. Brussels, with roughly 1 million inhabitants, dumped its urban sewage directly to the Senne river. Since then, government efforts have reduced the backlog in urban wastewater treatment. In 2001 the first treatment plant for Brussels, treating a third of its sewage, was put in place. The unsatisfactory situation of the mid-2000s (Figure 11) has improved significantly and by 2010 the number of agglomerations with insufficient treatment was reduced to 1 in Flanders and halved to 30 in Wallonia. ${ }^{22}$ A large part of the success in Flanders was due to large regional subsidies to municipalities and a special-purpose public private partnership (OECD, 2007c). In 2009, a second treatment plant for Brussels was operational, ensuring that the majority of households in the area is connected to treatment. Nevertheless, by 2010, Belgium still had not implemented the urban wastewater treatment directive, for which it is to be fined. ${ }^{23}$ Full compliance is not expected before 2013.

22. The assessment is done by the European Commission in light of the 1991 Urban Wastewater Treatment Directive. Under the legislation, all urban waste water generated by agglomerations of over 10000 inhabitants should be collected and treated before being discharged. Belgium has designated its entire national territory as a "sensitive area", the treatment must be more stringent to significantly reduce phosphorous and nitrate levels in waters before they are discharged.

23. In June 2010 the Commission has asked the Court to impose a lump-sum fine of more than $€ 15$ million and a daily penalty payment of nearly $€ 62000$. 
Figure 11. The share of population connected to wastewater treatment is low As a percentage of national population, ${ }^{1} 2009$ or latest available

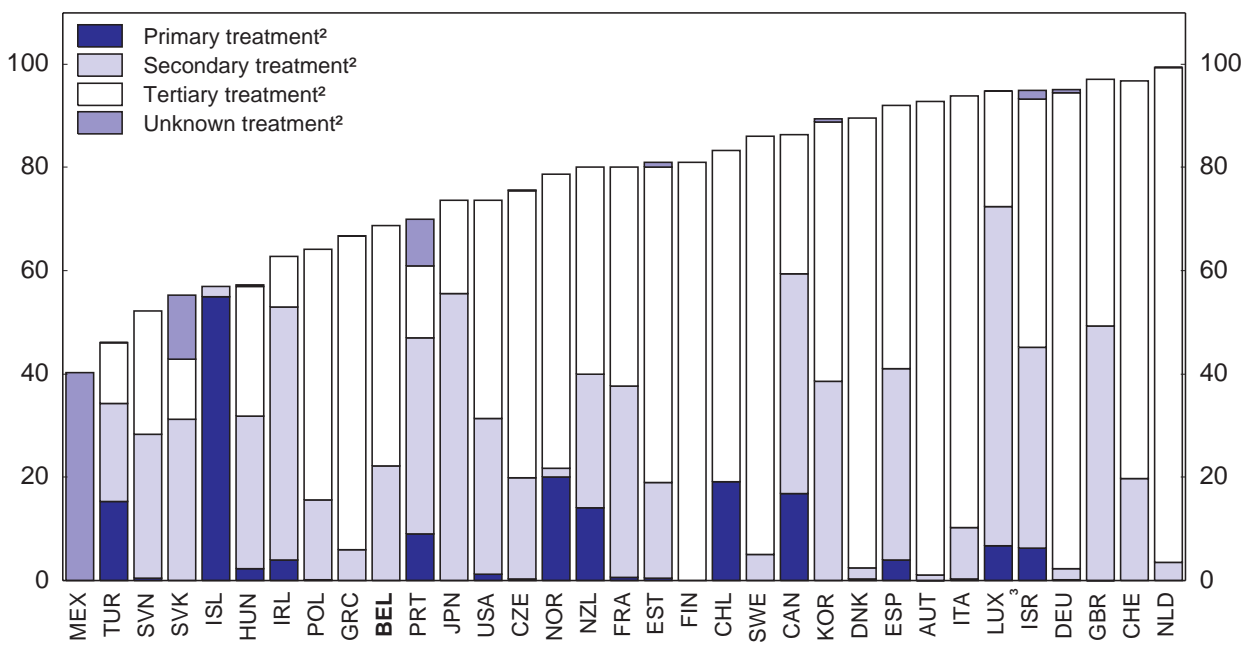

1. The last available year is 2008 for Austria, Czech Republic, Portugal, Mexico, Spain, Turkey and the United States; 2007 for Belgium, Germany and Ireland; 2006 for Canada, Hungary and Sweden; 2005 for Slovak Republic, Switzerland, Iceland and Italy; 2004 for France, 2003 for Luxembourg, 2002 for Finland and 1999 for New Zealand.

2. Primary treatment consists in physical and mechanical processes which result in decanted effluents and separate sludge. Secondary treatment consists in biological treatment technologies and tertiary treatment consists in advanced treatment technologies (chemical processes).

3. The statistical data for Israel are supplied by and under the responsibility of the relevant Israeli authorities. The use of such data by the OECD is without prejudice to the status of the Golan Heights, East Jerusalem and Israeli settlements in the West Bank under the terms of international law.

Source: OECD, Environment Database.

Water quality remains poor, with the EU water framework directive not being implemented due to gaps in the harmonisation of definitions (among regions), in monitoring and in measures taken. Less than a fifth of surface waters were classified as not at risk of fulfilling EU ("good status") targets for 2015, one of the poorest performances of the EU15 (EC, 2007 and EEB, 2010). National classifications for 2007-09 show very poor surface and ground water quality, particularly in Flanders (UNECE, 2010). After an improvement in the early 2000 s, non-costal bathing water quality returned to poor levels with $13 \%$ of areas nationwide (primarily in the south of the country) below minimum standards and monitoring problems (EEA, 2009).

The regional division of powers may complicate the conduct of effective water policies, given that the two main river basins do not follow regional borders. While the Belgian governments are co-operating within international basin bodies, internal co-ordination failure is particularly visible in the Scheldt basin, the recipient of Brussels wastewater (EEB, 2010). Hence, there is a need for either a national body or interregional bodies responsible for river basins to be created in order to ensure cross-border co-ordination and facilitate international co-operation. Such a reform would be in line with the requirements of the EU Water directive, which stipulates basin-based river management, but would avoid bureaucratic complications arising from separate river-basin authorities in each of the regions.

Water provision (and sanitation) is a municipality responsibility which is usually delegated to intermunicipal organisations. Currently, all three regions have different water pricing schemes, with a free quota in Flanders and cheap quotas in the two other regions. All three pricing strategies are based on a fixed fee and a variable per-cubic-metre price aimed at reflecting costs of distribution, capital and wastewater treatment. The variable price is lower for large users in all three regions. Given the persistent 
problems with assuring adequate treatment, it is likely that the incentives for private investors to provide the services are insufficient. This can be improved by reviewing the charges for treatment to ensure polluters pay for the marginal generated externality in the case of (large) enterprises (basing the charge on pollution content of the discharge, as currently done in Flanders). For households, where monitoring and enforcement are likely to be costly, but the pollution load relatively uniform, wastewater treatment charges should remain incorporated in the water price, but transferred directly to the treatment provider (which is already the case in Flanders) rather than to the general regional budget. Overall this may result in increasing the tariff-financing of wastewater collection and treatment infrastructure. Finally, more competitive forces in treatment provision should be encouraged by lower barriers to entry and wider public tendering of contracts.

\section{Agriculture is a major source of water pollution}

Belgian agriculture is among the most intensive in the OECD, with particularly intensive animal husbandry and pesticide and synthetic fertiliser use having a negative impact on water quality. Despite being a heavy polluter, the sector benefits from extensive subsidies and preferential tax treatment, to a higher degree than in many OECD countries (OECD, 2010). In particular, federal subsidies aimed at increasing the reliance on bio-fuels (in line with the 20/20/20 goals) come at a high abatement costs (per tonne of $\mathrm{CO}_{2}$ ): EUR 200 in the case of biofuels and EUR 600-800 in the case of ethanol (with extreme cases of up to EUR $2000-4$ 400, Kutas et al., 2007). A more efficient strategy would be to impose a strict mandatory share of biofuels in the fuel mix, similarly as in the GC market, and allow the market to establish the price of individual biofuels. The sector is also fully exempt from excise taxation on fuels and road and motor vehicle taxation, hence is exposed to lower incentives in terms of GHG reduction targets. ${ }^{24}$

In the area of water pollution, to combat phosphorus and nitrogen pollution from fertilisers regional manure management systems introduced over the past decade and have led to substantial improvement (Gybels et al., 2009). Additional benefits could be gained from a common system across the country, particularly if, as has been proposed in Flanders, a system of tradable manure rights is introduced. In this respect, a uniform, country-wide balancing system, with farm-level nutrient (nitrogen and phosphorus) accounts and quotas, could prove an effective way to curb excessive manure and use of synthetic fertiliser. Nutrient surplus above the quota would be subject to taxation. A system of this type is in place in Denmark (OECD, 2007b). Finally, excessive pesticide use should be curbed through an externality tax. In the 1990s, the eco-tax on pesticides in place in the 1990s, exempted the agricultural sector. This was replaced by a federal tax on pesticides, linked to pollution content (by category), which can be considered a step in the right direction, and by stricter command and control regulation, with some visible shifts to less polluting pesticide. However, the pesticide tax is several times lower for professional users (that is the bulk of users) and generally fairly low, in part due to cross-border leakage considerations. ${ }^{25}$ As the effectiveness of a sales tax on pesticide may be mitigated by cross-border trade due to the small country size, it would ideally be co-ordinated with neighbouring countries. If this is not possible, taxing the use of pesticide (rather than purchase) should be considered.

\section{Environmental tools and policies should be co-ordinated and realigned}

As mentioned throughout the paper, the division of environment-related powers and responsibilities in Belgium is complex and fragmented. The three regions have a large share of responsibilities concerning environmental policies and directly related areas: agriculture, economic policy, energy, transport and R\&D

24. Nevertheless, the majority of agricultural GHG emissions take the form of methane (from enteric fermentation and manure management) and nitric oxide (soil and manure management).

25. A reason sometimes cited to back a higher tax for non-professionals is the fact that they may use pesticides in a more harmful way (e.g. due to poor awareness). 
(Table 8). Health care policy, where many of the consequences of environmental developments eventually occur, is largely federal, though shared with the (language) communities, which also deal with (environmental) education. The federal level has most taxation powers. Each government has sovereign powers in its area of decisions there are no mandatory co-ordination or binding crisis-resolution instruments, implying the need for intensive co-operation and consultation. A vast number of bodies have been formed for this purpose, such as the National Climate Commission in climate change and the CONCERE/ENOVER in energy. Moreover, as in other member states, a significant share of environmental, agricultural and economic aspects is dealt with at the EU level.

Table 8. Division of responsibilities in environmental and related policies is complicated

\begin{tabular}{|c|c|}
\hline Federal level & Sub-federal level (Regions, unless otherwise indicated) \\
\hline \multicolumn{2}{|c|}{ ENVIRONMENT AND CLIMATE } \\
\hline $\begin{array}{l}\text { standards, certificates and labelling for products, } \\
\text { encouraging sustainable production and } \\
\text { consumption, } \\
\text { negotiating international agreements, } \\
\text { radiation protection and nuclear waste, } \\
\text { protection of marine environment. }\end{array}$ & $\begin{array}{l}\text { protection of ground, underground, water and air, } \\
\text { noise pollution, } \\
\text { zoning laws, housing, } \\
\text { water policies, } \\
\text { agriculture. }\end{array}$ \\
\hline \multicolumn{2}{|c|}{ ENERGY } \\
\hline $\begin{array}{l}\text { - security of supply, } \\
\text { - nuclear energy (fuel cycles and R\&D) } \\
\text { - off-shore wind energy } \\
\text { - production and transmission of energy } \\
\quad \text { (grid }>70 \mathrm{kV} \text { ) and large storage infrastructure, } \\
\text { - distribution and transmission tariffs } \\
\text { - monitoring retail prices (since 2008). }\end{array}$ & $\begin{array}{l}\text { - promotion of efficient energy use and renewables, } \\
\text { - energy R\&D (excluding nuclear), } \\
\text { - distribution (municipalities) and transmission of electricity } \\
\text { (grid }<70 \mathrm{kV} \text { ) and gas, } \\
\text { - district heating equipment and networks, } \\
\text { - recovery of waste energy from industry. }\end{array}$ \\
\hline \multicolumn{2}{|c|}{ FISCAL TOOLS } \\
\hline most taxes, including energy and environmental. & $\begin{array}{l}\text { environmental subsidies, } \\
\text { taxation in areas not taxed by the federal level such as } \\
\text { vehicle taxes (circulation and registration), euro vignette. }\end{array}$ \\
\hline \multicolumn{2}{|r|}{ TRANSPORT } \\
\hline $\begin{array}{l}\text { national railway, } \\
\text { national airport (Brussels). }\end{array}$ & $\begin{array}{l}\text { public transport, } \\
\text { transport infrastructure, water pipelines. }\end{array}$ \\
\hline \multicolumn{2}{|c|}{ HEALTH } \\
\hline $\begin{array}{l}\text { regulation and financing of compulsory health } \\
\text { insurance, } \\
\text { financing hospitals and heavy medical care, } \\
\text { hospital accreditation criteria and professional } \\
\text { qualifications, } \\
\text { registration and price control of pharmaceuticals. }\end{array}$ & $\begin{array}{l}\text { language-community responsibilities: } \\
\text { health promotion and education, } \\
\text { maternity and child health services; aspects of elderly care, } \\
\text { implementation of hospital accreditation criteria, } \\
\text { financing of hospital investment. }\end{array}$ \\
\hline
\end{tabular}

Sources: International Energy Agency and OECD Economic Surveys of Belgium (2007 and 2009).

There are clear advantages of delegating selected aspects of environmental policies to the regional level or potentially even the municipality level, given the better ability to adjust policies to the local needs. However, climate change and pollution do not respect borders, and therefore the current set-up increases the burden of environmental policies and reduces their effectiveness, thereby making Belgians poorer overall: 
- The bodies responsible for environmental policies do not have the powers to use the most costefficient tools. The regions lack of taxation power, prevents widespread use of externality taxation. Instead regions revert to more costly and less effective subsidy measures, which often reduce R\&D incentives by choosing winning technologies (De Serres et al., 2010). The result - a multitude of instruments often leading to disappointing results, such as in energy efficiency investments in housing.

- The administrative borders inhibit the implementation of efficient nationwide policies. In areas such as water policies, air pollution management or transport policies, regional borders are unlikely optimal boundaries.

- $\quad$ Smaller markets prevent the exploitation of the economies of scale and scope in environmental policies, as visible for instance in the existence of (five) separate regional markets for green power certificates, hindering cost-equalisation of renewable energy use across the country.

The division of environment-related responsibilities in a federation has been reviewed in a general context in the previous Survey (OECD, 2009a). As a conclusion: i) an appropriate division of powers should follow the division of responsibilities so that each government body can fulfil its tasks optimally; and ii) in areas where significant economies of scale or scope can be reaped, at the minimum close and swift co-operation should be ensured and moving competencies to the national level could be beneficial. An example of such nation-wide co-operation can be found in case of waste-management (batteries) where a single national entity takes care of collection and recycling (OECD, 2007a).

More rigour in planning and decision-making could facilitate choosing the optimal solutions for reaching environmental goals. According to a review of federal climate change policies, the lack of proper evaluation of the costs and effects of (federal) measures means that decisions have little to do with economic reasoning (Cour des Comptes, 2009). Independent critical evaluations of regional environmental policies and the interaction with policies at different levels are hardly available. In order to introduce more economic rationale into environmental policy design, comparable cost benefit analysis (CBA) of all important environment-related policies (and major investments above a certain threshold) should become mandatory. ${ }^{26}$ The independent analysis should apply national guidelines on parameters and methodology and include the evaluation and assignment of monetary values to environmental effects, for example on human health. Decisions to deviate from the CBA conclusions should be necessarily publicly explained. Ex post analysis should follow up on existing and future projects and policies to provide feedback for improvement of the CBA tool itself.

26. At the moment cost benefit analysis (CBA) is generally done at the regional level for investment major projects (as this is where they usually occur). Environmental Impact Assessment, an EU requirement, is less analytically rigorous and concerns only environmental impact. 
ECO/WKP(2011)63

\section{Box 8. How to achieve greener growth in the Belgian federation}

\section{Reduce greenhouse gas emissions and air pollutants in a cost-efficient manner}

- Introduce a carbon tax for the sectors not subject to the EU Emission Trading Scheme (part of industry, transport, housing and services). The level of the tax should be in line with emission reduction commitments. Speed up the introduction of auctioning of the ETS permits and consider taxing away windfall gains arising from the grandfathering of permits. Scrap measures that discourage energy savings (such as exemptions and reductions for large users).

- Unify green certificates (GC's) across the country to replace the five currently existing, to benefit from the economies of scale and scope and ensure that renewable energy is developed where it is most viable. Consider scrapping the minimum prices for various types of renewable energy in order not to promote inefficient technologies and allow the market (under the GC scheme) to decide the price and mix of renewable energy.

- Encourage investment in renewable energy by removing regulatory obstacles and publishing credible paths for the minimum requirements in the energy mix. Consider pursuing the targets for biofuels in a similar system.

- Realign excise taxes on fuels with environmental marginal externalities. Take steps towards more uniform taxation of different uses of the same fuels. Increase the relative taxation of diesel with respect to gasoline to reduce the diesel bias and the associated environmental externalities. Scrap the reimbursement of part of the diesel price for professional use.

- Implement country-wide road pricing for freight. Link distance-based user charges to associate externalities, including pollution (by class of vehicle). Extend the scheme to company cars, and eventually including passenger cars. The scheme would benefit from co-ordination with neighbouring countries. Consider congestion charges, particularly around Brussels, either independently or as part of road pricing.

- $\quad$ Phase out the numerous subsidies to private transport in order not to encourage moving away from the workplace or the excessive use of cars. The commuting allowance, particularly for road transport, should be focused on persons otherwise at risk of dropping out of the job market, and could take the form of a lump-sum allowance.

- Increase the flexibility and demand-responsiveness of public transport to increase its attractiveness through better co-ordination among regions and the federal train system, lower entry barriers, public tendering and the possibility for operators to propose new routes.

- Drastically reduce the numerous subsidies for energy efficiency investment in housing and for industry. At the least, make sure that measures at different levels of government are co-ordinated in order to reach targets. Focus measures on liquidity constrained low-income households. Improve the energy efficiency awareness among households.

- Phase out the social energy tariffs and VAT reductions in order to expose households to the same marginal energy saving incentives. Replace these with income subsidies for low income households.

Improve water quality

- Delegate responsibilities for water policies to an independent national authority or river-basin authorities.

- Review wastewater treatment charges to ensure polluters pay the full marginal costs of environmental externalities. Encourage more competitive provision of wastewater treatment.

- Introduce a pollution-content based pesticide tax on sales or application. Consider a country-wide manure and synthetic fertiliser management scheme, with balancing farm-level accounts and quotas for nutrients.

\section{The organisation of environmental policies needs to promote cost-efficiency}

- Increase the reliance on taxation of environmental externalities (rather than subsidies or command and control measures) to implement environmental policies.

- Reconsider the division of environmental responsibilities and powers in the federation with an aim of assuring: that the responsible bodies have the most cost-efficient tools to achieve their goals (e.g. taxation powers); and the exploitation of the economies of scale and scope (e.g. in renewable energy).

- Increase the role of economic considerations in environmental policies by introducing compulsory cost-benefit analysis for major investment projects and policies. Agree on national guidelines on parameters and methodology and follow up with ex post analysis. 


\section{Bibliography}

AEON (2010), "Renewable energy non-cost barriers - Country Report Belgium Study for EC DG Energy", ECORYS Report.

Bassilière, D. et al. (2005), "Variantes de réduction des cotisations sociales et de modalités de financement alternatif", Bureau Fédéral du Plan, Working Paper No. 97.

Bassilière, D., F. Bossier and F. Verschueren (2009), "Economic impacts of tax-shifting operations", Bureau Fédéral du Plan, Working Paper 11-09.

Bossier, F. et al. (2008), "Impact of the EU Energy and Climate Package on the Belgian energy system and economy - Study commissioned by the Belgian federal and three regional authorities", Federal Planning Bureau Working Paper No. 21/08.

Braathen, N.A. (2011), " $\mathrm{CO}_{2}$-based taxation of motor vehicles", in T. Zachariadis (forthcoming), Cars and Climate Policy: The European Experience, Springer verlag.

Carlier, P., S. Fontaine and B. Monnier (2007), « La qualité de l'habitat wallon : synthèse des résultats d'une enquête », Les Echos du logement, Ministère de la Région wallonne, pp. 1-15.

CE Delft (2008), Handbook on estimation of external costs in the transport sector, CE Delft.

De Coninck, R. and G. Verbeeck (2005), “Analyse technico-économique de la rentabilité des investissements en matière d'économie d'énergie", Institut bruxellois pour la gestion de l'environnement.

Cour des comptes (2009), "Politique climatique fédérale - mise en œuvre du protocole de Kyoto", Rapport de la Cour des comptes transmis à la Chambre des représentants, Bruxelles, juin 2009.

CREG (2008), “Étude complémentaire à l'étude (F) 060309-CDC-537 relative à l'impact du système des quotas d'émissions de $\mathrm{CO}_{2}$ sur le prix de l'électricité en Belgique de 2005 à 2007”.

CREG (2010a), "Étude sur une première estimation du coût des mesures visées à l'article 7 de la loi du 29 avril 1999 relative à l'organisation du marché de l'électricité".

CREG (2010b), “Étude relative aux différents mécanismes de soutien de l'électricité verte en Belgique”.

DEFRA (2011), "Trends in $\mathrm{NO}_{\mathrm{x}}$ and $\mathrm{NO}_{2}$ emissions and ambient measurements in the UK", version $3^{\text {rd }}$, March 2011.

Deutsch F. et al. (2010), Zwevend stof en fotochemische luchtverontreiniging. Visionair scenario Milieuverkenning 2030, studie uitgevoerd in opdracht van de Vlaamse Milieumaatschappij, MIRA, MIRA/2010/09, VITO.

Duval, R. (2008), “A Taxonomy of Instruments to Reduce Greenhouse Gas Emissions and their Interactions", Economics Department Working Paper No. 636, OECD, Paris.

European Environmental Agency (2009), "Bathing water results 2009 - Belgium”, EEA Report. 
European Environmental Bureau (2010), "10 years of the Water Framework Directive: A Toothless Tiger? A snapshot assessment of EU environmental ambitions".

European Commission (2007), "Towards Sustainable Water Management in the European Union - First stage in the implementation of the Water Framework Directive 2000/60/EC", Commission Staff Working Document.

European Commission (2011), "Energy taxation: Commission promotes energy efficiency and more environmental friendly products", Press Release IP/1 1/468, Brussels, 13 April 2011.

Eliasson, J. (2010), "So you're considering introducing congestion charging? Here's what you need to know" - FAQ based on Stockholm's experiences, Discussion Paper No. 2010-4, International Transport Forum, OECD.

EPI (2010), “Environmental Performance Index 2010”, Yale Center for Environmental Law \& Policy, Yale University and Center for International Earth Science Information Network, Columbia University.

FPB (2010), “Perspectives économiques 2010-2015”, Bureau Fédéral du Plan, May 2010, Brussels.

Fierens, F., G. Dumont and C. Demuth (2006), "Estimation of the exceedance of the European PM10 limit values in Belgian cities and streets during the period 2005-2010-2015”, IRCEL-CELINE, Brussels.

Fosgerau, M. and K. Van Dender (2010), "Road pricing with complications”, Discussion Paper No. 2010-2, International Transport Forum, OECD/ITF, Paris.

Goodwin, P.J. Dargay and M. Hanly (2004), "Elasticities of Road Traffic and Fuel Consumption with Respect to Price and Income: A Review", Transport Reviews, Vol. 24, No. 3, 275-292.

Guisson, R. and D. Marchal (2008), "Sustainable International Bioenergy Trade - Securing Supply and Demand”, Country Report Belgium, IEA BIOENERGY - TASK.

Gybels, K., et al. (2009), "Nutrient Balance for Nitrogen”, Statistics Belgium, Working Paper No. 22.

Heylen, K., M. Le Roy, S. Vandenbroucke, B. Vandekerckhove and S. Winter (2007), Wonen in Vlaanderen.

High Council of Finance (2009), "La politique fiscale et l'environnement”, Conseil Supérieur des Finances, septembre 2009.

Hertveldt, B., B. Hoornaert and I. Mayeres (2009), "Perspectives à long terme de l'évolution des transports en Belgique : projection de référence", Bureau Fédéral du Plan, Planning Paper 107.

Hoornaert, B., I. Mayeres and M. Nautet (2009), "Les comptes satellites des transports et les externalités", Bureau Fédéral du Plan, Working Paper 15-09.

INFRAS (2004), "External costs of transport” - update study, INFRAS/IWW, Zurich.

International Energy Agency (2010), Energy Policies of IEA Countries: Belgium in-depth review 2009, Paris. 
Koźluk T. (2009), "Promoting competition to strengthen economic growth in Belgium", Economics Department Working Paper Series No. 736, OECD, Paris.

Koźluk T. (2010), "How the transport system can contribute to better economic and environmental outcomes in the Netherlands", Economics Department Working Paper Series No. 804, OECD, Paris.

Kuik, O., L. Brander and R.S.J. Tol (2009), "Marginal abatement costs of greenhouse gas emissions: A meta-analysis", Energy Policy, 37.

Kutas, G., C. Lindberg and R. Steenblik (2007), "Biofuels- at what cost? Government support for ethanol and biodiesel in the European Union", Prepared for The Global Subsidies Initiative (GSI).

Le Soir (2010), "Bruxelles, numéro un des bouchons”, Le Soir, 21/04/2010, Author: De Schrijver, M.

McKinsey (2009), "Pathways to world class energy efficiency in Belgium”, McKinsey \& Company.

Mossakowski, M. (2011), Is taxation of company cars in Belgium environmentally harmful? Presented at European expert platform on environmental taxation and green fiscal reform conference "Is the tax treatment of company cars environmentally harmful in the European Union?" Green Budget Europe and DG TAXUD, European Commission, Brussels - 28 February 2011.

OECD (2001), OECD Economic Surveys: Belgium 2001, OECD Publishing.

OECD (2007a), OECD Environmental Performance Reviews: Belgium 2007, OECD Publishing.

OECD (2007b), "Instrument Mixes Addressing Non-Point Sources of Water Pollution”, OECD Papers, Vol. 7/8.

OECD (2007c), Mechanisms for Managing Public Environmental Expenditure in Selected OECD Countries, OECD Publishing.

OECD (2009a), OECD Economic Surveys: Belgium 2009, OECD Publishing.

OECD (2009b), "The scope for $\mathrm{CO}_{2}$-based differentiation in motor vehicle taxes - in equilibrium and in the context of the current global recession", Working Party on National Environmental Policies Working Group on Transport, OECD, Paris.

OECD (2010), Taxation, Innovation and the Environment, OECD Publishing.

OECD (2011a), OECD Economic Surveys: Belgium 2011, OECD Publishing.

OECD (2011b), "Interactions between emission trading systems and other overlapping policy instruments", Joint Meeting of Tax and Environment Experts, 20-21 May 2011, Paris.

Renard F. (2008), "Performance énergétique : les choix les plus rentables", Les Échos du logement, Ministère de la Région wallonne, No. 3, pp. 16-21.

De Serres, A., G. Nicoletti and F. Murtin (2010), "A framework for the assessing green growth policies", OECD Economics Department Working Paper, No. 774, OECD, Paris.

Schmitz, T. (2011), "Price elasticities of fuel demand in Belgium", OECD Economics Department Working Paper forthcoming. 
Sijm, J. et al. (2008), “The impact of the EU ETS on electricity prices", Final report to DG Environment of the European Commission.

SPF Mobility (2010), Deuxième diagnostic fédéral des déplacements domicile-travail - résultats, Instituut voor de autoCaren de autoBus v.z.w.rapport pour SPF Mobility et Transport.

Spies B. and B. Buxant (2008), "Des fonds publics pour le PV : est-ce efficace ?”, Valériane 71, NatPro.

TML (2006), "Les émissions du trafic routier en Belgique 1990-2030”, Transport et Mobilité Leuven.

Tol, R. (2009), "The economic effects of climate change", Journal of Economic Perspectives, Vol. 23, pp. 29-51.

UNECE (2010), "Belgium - Summary report under the protocol on water and health", Geneva.

VAB (2008), « Succès du diesel en Belgique, une évolution polluante », http://www.vab.be/fr/actuel/dossiers/article.aspx?Id=286.

WWF (2010), Living planet report 2010, WWF, Bland. 
ECO/WKP(2011)63

\section{WORKING PAPERS}

The full series of Economics Department Working Papers can be consulted at www.oecd.org/eco/workingpapers/

893. Green growth and climate change policies in New Zealand

(September 2011) by Alexandra Bibbee

892. Has deregulation increased investment in infrastructure? Firm-level evidence from OECD countries

(September 2011) by Sónia Araújo

891. Ensuring a Sustainable and Efficient Fishery in Iceland (September 2011) by Gunnar Haraldsson and David Carey

890. Japan's New Growth Strategy to create demand and Jobs (September 2011) by Randall S. Jones and Byungseo Yoo

889. Labour market reforms in Japan to improve growth and equity (September 2011) by Randall S. Jones and Satoshi Urasawa

888. Education reform in Japan

(September 2011) by Randall S. Jones

887. The Political Economy of Climate Change Mitigation Policies: How to Build a Constituency to Address Global Warming?

(August 2011) by Alain de Serres, John Llewellyn and Preston Llewellyn

886. Climate-Change Policy in the United Kingdom

(August 2011) by Alex Bowen and James Rydge

885. Improving Access and Quality in the Indian Education System

(August 2011) by Sam Hill and Thomas Chalaux

884. How Institutions Shape the Distributive Impact of Macroeconomic Shocks: A DSGE Analysis (July 2011) by Rudiger Ahrend, Charlotte Moeser and Tommaso Monacelli

883. Can India Achieve Double-Digit Growth?

(July 2011) by Richard Herd, Paul Conway, Sam Hill, Vincent Koen and Thomas Chalaux

882. Predicting peaks and troughs in real house prices

(July 2011) by Linda Rousová and Paul van den Noord

881. Public sector spending efficiency in Estonia: healthcare and local government (July 2011) by Zuzana Smidova

880. How to move Product Market Regulation in New Zealand back towards the frontier (July 2011) by Paul Conway

879. Financial sector reform in India: time for a second wave?

(July 2011) by Richard Herd, Vincent Koen, Ila Paitnak and Ajay Shah 
878. Policies to rebalance housing markets in New Zealand (July 2011) by Calista Cheung

877. The sharing of macroeconomic risk: Who loses (and gains) from macroeconomic shocks (July 2011) Rudiger Ahrend, Jens Arnold and Charlotte Moeser

876. Estonia: making the most of globalisation (June 2011) Robert Price and Andreas Wörgötter

875. The effects of downturns on labour force participation: evidence and causes (June 2011) Romain Duval, Mehmet Eris and Davide Furceri

874 A dynamic factor model for world trade growth (June 2011) Stéphanie Guichard and Elena Rusticelli

873. Towards a better understanding of the informal economy (May 2011) Dan Andrews, Aida Caldera Sánchez and Åsa Johansson

872. Tax competition between sub-central governments (May 2011) Hansjörg Blöchliger and José-Maria Pinero-Campos

871. The growth effects of current account reversals: the role of macroeconomic policies (May 2011) Luiz de Mello, Pier Carlo Padoan and Linda Rousová

870. Les politiques du logement en France (May 2011) Bénédicte Rolland

869. How important is wealth for explaining household consumption over the recent crisis? An empirical study for the United States, Japan and the euro area (May 2011) Clovis Kerdrain

868. Adjusting fiscal balances for asset price cycles (May 2011) Robert Price and Thai-Thanh Dang

867. Improving the functioning of the housing market in the United Kingdom (May 2011) Christophe André

866. An analysis of demand for foreign exchange reserves (May 2011) Peter Vujanovic

865. Episodes of large capital inflows and the likelihood of banking and currency crises and sudden stops

(May 2011) Davide Furceri, Stephanie Guichard and Elena Rusticelli

864. The effect of episodes of large capital inflows on domestic credit

(May 2011) Davide Furceri, Stephanie Guichard and Elena Rusticelli

863. Medium-term determinants of international investment positions: the role of structural policies (May 2011) Davide Furceri, Stephanie Guichard and Elena Rusticelli. 